Review

\title{
Transition Metal Carbides and Nitrides as Electrode Materials for Low Temperature Fuel Cells
}

\section{Dong Jin Ham and Jae Sung Lee*}

Eco-friendly Catalysis and Energy Laboratory (NRL), Department of Chemical Engineering, School of Environmental Science and Engineering, Pohang University of Science and Technology, San 31, Hyoja-dong, Pohang 790-784, Korea; E-Mail: nicehdj@ postech.ac.kr

* Author to whom correspondence should be addressed; E-Mail: jlee@postech.ac.kr;

Tel.: +82-54-279-2266; Fax: +82-54-279-5528.

Received: 28 August 2009 / Accepted: 25 September 2009 / Published: 13 October 2009

\begin{abstract}
Transition metal carbides (TMCs) and transition metal nitrides (TMNs) have attracted attention as promising electrocatalysts that could replace noble metals of high price and limited supply. Relative to parent metals, TMC and TMN behave like noble metals for electrochemical reactions such as oxidation of hydrogen, $\mathrm{CO}$ and alcohols, and reduction of oxygen. When TMC and TMN are combined with other metals, the electrocatalytic synergy is often observed in electrochemical reactions. Thus, combinations with a minute amount of $\mathrm{Pt}$ or even non-Pt metals give performance comparable to heavily loaded Pt-based electrocatalysts for low temperature fuel cells. It appears that TMC based electrocatalysts are more active as anode catalysts for oxidation of fuels, whereas TMN based catalysts are more active for cathode catalysts for oxygen reduction and more stable.
\end{abstract}

Keywords: transition metal carbide; transition metal nitride; low temperature fuel cells

\section{Introduction}

Recently, the attention on clean energy has increased due to the limitation of hydrocarbon based energy sources and for protection of a clean environment [1-3]. Fuel cells have been considered as effective energy devices with a variety of applications from microdevices of milliwatt $(\mathrm{mW})$ scale to large megawatt (MW) scale electric generators. They convert fuels into electricity with higher efficiency than Carnot cycle devises, and can be intrinsically environmentally friendly, with much less emission of 
pollutants, by using clean fuels derived from renewable energy sources. They are pivotal power generating devises that would play a key role in upcoming hydrogen economy $[4,5]$.

As fuel cells convert chemical energy into electrical energy, they need a continuous supply of "fuels" for power generation. Fuel cells are specified by their electrolyte, operating temperatures and fuel types. Among them, the proton exchange membrane fuel cell (PEMFC) and direct methanol fuel cell (DMFC) represent the most popular low temperature fuel cells. These fuel cells operate below $373 \mathrm{~K}$ and are suitable for mobile devices, vehicles and residential power sources, due to their low operating temperatures, high efficiency and rapid start-up times (Figure 1) [6-10].

Figure 1. The schematic process for power production in PEMFC. (Reprinted from Reference 25 with permission).

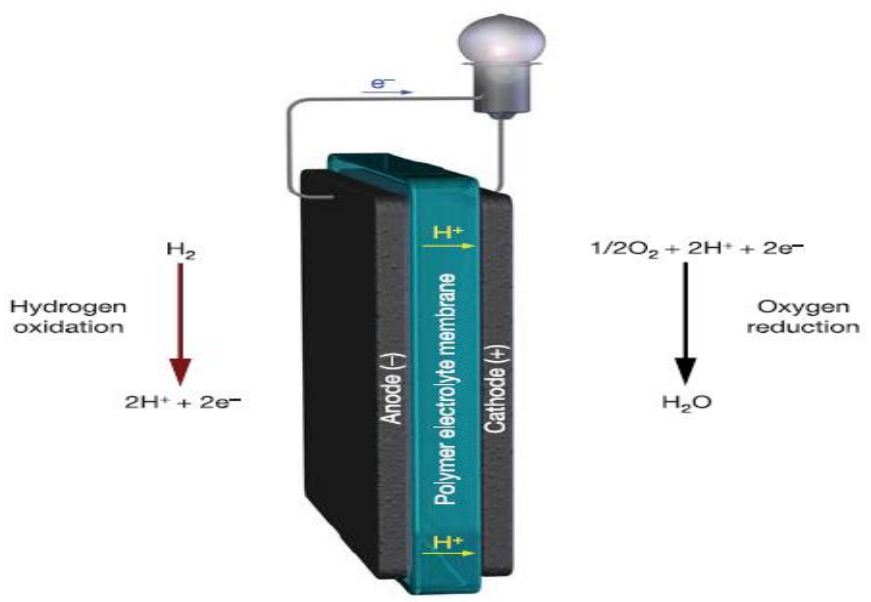

In low temperature fuel cell systems, hydrogen and methanol are employed as fuels for the anode side of PEMFC and DMFC, respectively. In the cathode side, the oxygen or air is supplied in both systems. Electrochemical oxidation of the fuels produces protons and electrons. The electrons are transferred to the cathode side via an outer circuit, and the protons are also transferred to cathode side through the electrolyte, i.e., a polymer membrane. The transferred electrons and protons are combined with oxygen on the cathode side to produce water as the final product. Thus the electric potential of the reaction is used as power source, i.e., $1.23 \mathrm{~V}$ and $1.08 \mathrm{~V}$ for PEMFC and DMFC (as theoretical potentials), respectively [3,10-12].

The most important component of low temperature fuel cells in terms of cost, performance and long-term stability is the membrane electrode assembly (MEA) consisting of the anode, cathode and electrolyte [13-19]. The price of membranes can be greatly reduced by large scale production as the fuel cells are commercially produced for widespread use. Yet, this cost improvement with large scale production cannot be realized for electrocatalysts [20-22]. The low temperature fuel cells operate under strongly acidic conditions $(\mathrm{pH}<2)$ originating from the mobility of protons. Under this acidic condition, the utilization of base transition metals such as cobalt and iron is restricted by serious dissolution problems, even though they have catalytic activity for the redox reactions [13,23-26]. Noble metals such as Pt and Ru are used as electrocatalysts due to their high activity at low temperatures and the resistance to dissolution under acidic condition [13,27]. Since Pt is an expensive metal in limited supply, reducing the amount of its loading for electrode fabrication, or even better, replacing it with non-Pt 
metals of low cost, high performance and long-term stability, is a critically important topic of research for practical dissemination of fuel cell technology [25,28-34].

Various investigations have reported reduction or replacement of $\mathrm{Pt}$ in the anode side of low temperature fuel cells [35-37]. To reduce $\mathrm{Pt}$ usage, new techniques and materials have been proposed such as a decrease of Pt particle size for effective utilization of the surface [38-41], alloy formation with other metals $[13,35,42]$ and the use of carbon supports of various textures (e.g., 1-D structures) $[38,43,44]$. It has been estimated that the amount of Pt can be reduced to $0.05-0.4 \mathrm{mg}_{\mathrm{Pt}} / \mathrm{cm}^{2}$ and 2-4 $\mathrm{mg}_{\mathrm{P}} / \mathrm{cm}^{2}$ in PEMFC and DMFC, respectively, without serious sacrifice in activity and electrochemical stability [45]. In addition, some non-Pt based electrocatalysts were also suggested for oxidation reaction, although their stability was not unequivocally established [27]. The technological development of cathode electrocatalysts is much slower than that of anode electrocatalysts because of the slow reaction kinetics for oxygen reduction. But the impact of new technological development is greater for cathode side because cathode employs much larger amount of $\mathrm{Pt}$ to compensate for the slow reaction kinetics. It is estimated that around $\sim 0.4 \mathrm{mg}_{\mathrm{Pt}} / \mathrm{cm}^{2}$ is needed for proper activity in PEMFC [13]. Thus, for commercialization of low temperature fuel cells, the amount of Pt should be reduced to 50\%-90\% of the current level in PEMFC vehicles [3]. In the long run, Pt should be totally substituted by non-Pt based electrocatalyst for anode and cathode sides considering the rarity of Pt. Even the stateof-the-art Pt/carbon electrocatalysts have not still reached desired level in terms of long-term stability because of the dissolution and aggregation of Pt particles and the carbon corrosion [47]. For application to transportation vehicles, PEMFC should satisfy 5,000-20,000 hrs operation without acute deactivation $[3,47]$. However, the current level is around $2,000 \mathrm{hrs}$. These results also indicate that the new electrocatalyst materials need to be developed for commercialization of low temperature fuel cells.

As potential substitutes for Pt as electrode material for low temperature fuel cells, transition metal carbides (TMCs) and transition metal nitrides (TMNs) have attracted attention as promising electrocatalysts. Relative to their parent transition metals, TMCs and TMNs behave like noble metals ( $\mathrm{Pt}, \mathrm{Pd}, \mathrm{Rh}$ and $\mathrm{Ru}$ ) for some chemical and electrochemical reactions, including oxidation of hydrogen, $\mathrm{CO}$, and alcohols, and reduction of oxygen [48,49]. These electrocatalysts have been utilized as active components by themselves, as support materials for other metals, and the second/third component for enhancement of electroactivities of other metals. In this review, the fundamental catalytic properties and various applications of TMCs and TMNs based materials as electrocatalysts at anode and cathode sides for low temperature fuel cells are discussed including their electrochemical stabilities. Recently, the various Pt-free electrocatalysts also have been reviewed including the tungsten carbide based materials as anode of low temperature fuel cells [27].

\section{Transition Metal Carbides (TMCs)}

Many transition metal carbides (TMCs) show good mechanical and chemical stability and resistance against corrosion under reaction conditions. These materials also show the various catalytic advantages over their parent metals in activity, selectivity, and resistance to poisoning. TMCs have been found to be good catalysts for a wide variety of reactions typically catalyzed by noble metals of high cost and limited supply [50]. The catalytic properties of TMCs have been reviewed [51-55] and references are available that cover more general properties of the materials [56-62]. 
The formation of TMCs is extensive throughout the Periodic Table. All transition metals form carbides except for the second and third row Group 9-10 metals ( $\mathrm{Rh}, \mathrm{Ir}, \mathrm{Pd}$, and $\mathrm{Pt}$ ). Table 1 provides a list of the most important carbides of Group 4-10 metals [61]. Among them, carbides of Group 4-6 are thermodynamically more stable and possess catalytic properties greatly improved over those of parent transition metals. The bimetallic and mixed carbides have also been considered as important materials due to their enhanced catalytic properties originated from the complementary effects of the each single metal carbide. Each carbide material should have the same crystal structure and similar ionic radius to form bimetallic carbides. Table 2 shows the various types of bimetallic and mixed carbides. Here, carbon resides in the interstitial sites formed by metal atoms [63]. Because of their importance as catalytic materials, this account focuses on the carbides of Group 4-6 metals [50].

Table 1. Transition metal carbides and their positions in the periodic table.

\begin{tabular}{|c|c|c|c|c|c|c|}
\hline Group 4 & Group 5 & Group 6 & Group 7 & Group 8 & Group 9 & Group 10 \\
\hline $\mathrm{TiC}$ & $\begin{array}{c}\mathrm{V}_{2} \mathrm{C} \\
\mathrm{V}_{4} \mathrm{C}_{3} \\
\mathrm{~V}_{6} \mathrm{C}_{5} \\
\mathrm{~V}_{8} \mathrm{C}_{7} \\
\mathrm{VC}\end{array}$ & $\begin{array}{l}\mathrm{Cr}_{23} \mathrm{C}_{6} \\
\mathrm{Cr}_{7} \mathrm{C}_{6} \\
\mathrm{Cr}_{3} \mathrm{C}_{2}\end{array}$ & $\begin{array}{c}\mathrm{Mn}_{23} \mathrm{C}_{6} \\
\mathrm{Mn}_{15} \mathrm{C}_{4} \\
\mathrm{Mn}_{3} \mathrm{C} \\
\mathrm{Mn}_{5} \mathrm{C}_{2} \\
\mathrm{Mn}_{7} \mathrm{C}_{3}\end{array}$ & $\begin{array}{c}\mathrm{Fe}_{3} \mathrm{C} \\
\mathrm{Fe}_{7} \mathrm{C} \\
\mathrm{Fe}_{2} \mathrm{C}\end{array}$ & $\begin{array}{l}\mathrm{Co}_{3} \mathrm{C} \\
\mathrm{Co}_{2} \mathrm{C}\end{array}$ & $\mathrm{Ni}_{3} \mathrm{C}$ \\
\hline $\mathrm{ZrC}_{1-\mathrm{x}}$ & $\begin{array}{c}\mathrm{Nb}_{2} \mathrm{C} \\
\mathrm{Nb}_{3} \mathrm{C}_{2} \\
\mathrm{NbC} \mathrm{C} \\
\mathrm{Nb}_{4} \mathrm{C}_{3}\end{array}$ & $\begin{array}{c}\mathrm{Mo}_{2} \mathrm{C} \\
\mathrm{Mo}_{3} \mathrm{C}_{2} \\
\mathrm{MoC}_{1-\mathrm{x}} \\
\mathrm{MoC}\end{array}$ & $\mathrm{TcC}(?)$ & RuC(?) & & \\
\hline $\mathrm{HfC}_{1-\mathrm{x}}$ & $\begin{array}{c}\mathrm{Ta}_{2} \mathrm{C} \\
\mathrm{Ta}_{3} \mathrm{C}_{2} \\
\mathrm{TaC} \\
\mathrm{Ta}_{4} \mathrm{C}_{3}\end{array}$ & $\begin{array}{c}W_{2} C \\
W_{1-x} \\
W C\end{array}$ & $\begin{array}{c}\operatorname{Re}_{24} \mathrm{C} \\
\operatorname{ReC}\end{array}$ & OsC(?) & & \\
\hline
\end{tabular}

The physicochemical properties of TMCs are related to their electronic structure. A systematic change is observed in their catalytic properties as one goes along the same row of the periodic table. TMCs have displayed unique surface reactivity and catalytic properties resembling those of noble metals rather than those of the parent metals. Furthermore, they demonstrate the hardness and brittleness of covalent solids, the high melting points and simple crystal structures typical of ionic solids, and electronic and magnetic properties similar to transition metals. Thus, the bonding in transition metal carbides can be described as a mixture of metallic, covalent, and ionic components [50].

Among the various tungsten carbides, WC is known for the Pt-like catalytic behavior [49,64]. Carbon $s p$-electrons increase the apparent electron-to-atom ratio, producing relatively more $\mathrm{Pt}$-like electronic structure. This has been sometimes wrongly interpreted as a claim that there is electron transfer from carbon to the tungsten $d$-band producing a Pt-like charge distribution and hence, Pt-like chemical properties [50]. The theoretical calculations and measurements by XPS and XANES indicate that the direction of electron transfer is from transition metal to carbon. The charge transfer decreases as the parent metals move from Group 4 to 6, probably due to the increase in their electronegativity. 
Table 2. Mixed Alloy Formation in Carbides and Nitrides.

\begin{tabular}{|c|c|c|c|c|}
\hline & \multicolumn{2}{|c|}{ Mixed Carbides } & Mixed Nitrides & Mixed Carbo-Nitrides \\
\hline $\begin{array}{c}\text { Continuous } \\
\text { Solid Solutions }\end{array}$ & \multicolumn{2}{|c|}{$\begin{array}{c}\mathrm{Fe}_{3} \mathrm{C}-\mathrm{Mn}_{3} \mathrm{C} \\
\text { HfC-TaC } \\
\text { NbC-TaC } \\
\text { NbC-TiC } \\
\text { NbC-VC } \\
\text { NbC-ZrC } \\
\text { TaC-TiC } \\
\text { TaC-VC } \\
\text { TaC-ZrC } \\
\text { TiC-VC } \\
\text { TiC-ZrC }\end{array}$} & $\begin{array}{c}\text { HfN-TaN } \\
\text { NbN-TiN } \\
\text { NbN-VN } \\
\text { NbN-ZrN } \\
\text { TiN-VN } \\
\text { TiN-ZrN } \\
\text { TiC-VN } \\
\text { TiC-ZrN } \\
\text { VC-VN } \\
\text { TiN-VC } \\
\text { ZrN-ZrC }\end{array}$ & $\begin{array}{l}\text { NbC-NbN } \\
\text { NbC-TiN } \\
\text { NbC-VN } \\
\text { NbN-TiC } \\
\text { NbN-VC } \\
\text { TiC-TiN }\end{array}$ \\
\hline $\begin{array}{c}\text { Partially } \\
\text { Miscible Solutions }\end{array}$ & $\begin{array}{c}\mathrm{Cr}_{4} \mathrm{C}-\mathrm{Fe}_{3} \mathrm{C} \\
\mathrm{Cr}_{3} \mathrm{C}-\mathrm{TiC} \\
\mathrm{Fe}_{3} \mathrm{C}-\mathrm{TaC} \\
\mathrm{Fe}_{3} \mathrm{C}-\mathrm{TiC} \\
\mathrm{Fe}_{3} \mathrm{C}-\mathrm{VC} \\
\mathrm{Fe}_{3} \mathrm{C}-\mathrm{ZrC} \\
\mathrm{Mo}_{2} \mathrm{C}-\mathrm{NbC} \\
\mathrm{Mo}_{2} \mathrm{C}-\mathrm{TaC} \\
\mathrm{Mo}_{2} \mathrm{C}-\mathrm{TiC} \\
\mathrm{Mo}_{2} \mathrm{C}-\mathrm{VC} \\
\mathrm{Mo}_{2} \mathrm{C}-\mathrm{ZrC}\end{array}$ & $\begin{array}{c}\text { NbC-W } 2 \mathrm{C} \\
\text { NbC-WC } \\
\text { TaC-W } \\
\text { TaC-WC } \\
\text { TiC-W } \\
\text { TiC-WC } \\
\text { VC-WC } \\
\text { VC-ZrC } \\
\text { W }_{2} C-Z r C \\
\text { WC-ZrC }\end{array}$ & $\begin{array}{c}\text { CrN-TaN } \\
\text { NbN-TaN } \\
\text { TaN-TiN } \\
\text { TaN-VN } \\
\text { TaN-ZrN } \\
\text { VN-ZrN } \\
\text { HfN-VN }\end{array}$ & $\begin{array}{c}\text { TaC-TaN } \\
\text { VC-ZrN } \\
\text { ZrN-NbC }\end{array}$ \\
\hline $\begin{array}{l}\text { Complex } \\
\text { Compounds }\end{array}$ & $\begin{array}{c}\text { Co-Mo-C } \\
\text { Cr-Nb-C } \\
\text { Fe-Mo-C } \\
\text { Fe-Ta-C } \\
\text { Fe-W-C } \\
\text { Ni-W-C } \\
\text { Mn-Mo-C } \\
\text { Mn-W-C }\end{array}$ & $\begin{array}{c}\text { Ni-Mo-C } \\
\text { V-Zr-C } \\
\text { Co-W-C } \\
\text { Mn-Ta-N } \\
\text { Ni-Mo-N } \\
\text { Ni-Ti-N } \\
\text { Ni-Ta-N }\end{array}$ & $\begin{array}{c}\text { Co-Ta-N } \\
\text { Cr-Ta-N } \\
\text { Co-Mo-N } \\
\text { Co-Ti-N } \\
\text { Fe-Ta-N }\end{array}$ & Fe-N-C \\
\hline
\end{tabular}

However, this charge transfer is not an important factor in determining catalytic properties of TMCs. Instead, the formation of carbides may modify the nature of the $d$-band of the parent metal relating to catalytic properties that are different from those of the parent metals but similar to those of Group 8-10 noble metals. The metal lattice expands and the metal-metal distance increases upon carbide formation. For example, the lattice constant of vanadium expands from 0.26 to $0.42 \mathrm{~nm}$, and that for niobium from 0.33 to 0.45 . The increase in metal-metal distance causes contraction of the metal $d$-band, which is proportional to the inverse fifth power of the metal-metal distance [65]. The $d$-band contraction would give a greater density of states (DOS) near the Fermi level in comparison with the parent metal. Thus TMCs could display catalytic properties resembling those of noble metals in various reactions, including electrochemical reactions. With these catalytic effects, TMCs have played pivotal roles as main catalysts and as promoters for other metals.

\subsection{Electrochemical Stability of TMCs}

The transition metal carbides (TMCs) have been considered as candidate electrocatalysts to replace the noble metals in low temperature fuel cells, which depend on a large amount of noble metals, especially Pt. TMCs have been employed as main catalyst, support, co-catalyst in various electrochemical systems. For electrochemical applications, the intrinsic stability is the primary concern. 
Among the metal carbides, tungsten carbides have been widely applied in the electrochemical systems including the electrocatalyst for low temperature fuel cells. This is due to its surface reactivity resembling that of platinum and stability in acidic medium. Tungsten carbides have several phases like tungsten mono-carbide (WC), tungsten semi-carbide $\left(\mathrm{W}_{2} \mathrm{C}\right)$ and cubic tungsten carbide $\left(\mathrm{WC}_{1-\mathrm{x}}\right)$. Among the various tungsten carbide phases, WC is known to be the most stable phase. Chen et al. reported that $\mathrm{WC}$ was more stable than $\mathrm{W}_{2} \mathrm{C}$ under anodic potential range [66]. As shown in Figure 2, $\mathrm{W}_{2} \mathrm{C}$ led to the anodic current peak at lower anodic potential (between $0.4 \mathrm{~V}$ and $0.6 \mathrm{~V}$ vs NHE) than WC (above $0.6 \mathrm{~V}$ vs NHE) in $0.5 \mathrm{M} \mathrm{H}_{2} \mathrm{SO}_{4}$ electrolyte. Furthermore, this anodic current at lower potential indicates that $\mathrm{W}_{2} \mathrm{C}$ is more easily oxidized than $\mathrm{WC}$, and implies that loss of $\mathrm{W}_{2} \mathrm{C}$ can occur in fuel cell application. In addition, $\mathrm{W}_{2} \mathrm{C}$ showed higher corrosion current than $\mathrm{WC}$ at the same potential [67].

Figure 2. Electrochemical $\mathrm{CV}$ measurements performed in $0.5 \mathrm{M} \mathrm{H}_{2} \mathrm{SO}_{4}$ saturated with $\mathrm{N}_{2}$ of $\mathrm{W}_{2} \mathrm{C}$ and $\mathrm{WC}$ films on carbon paper (Reprinted from Reference 66 with permission).
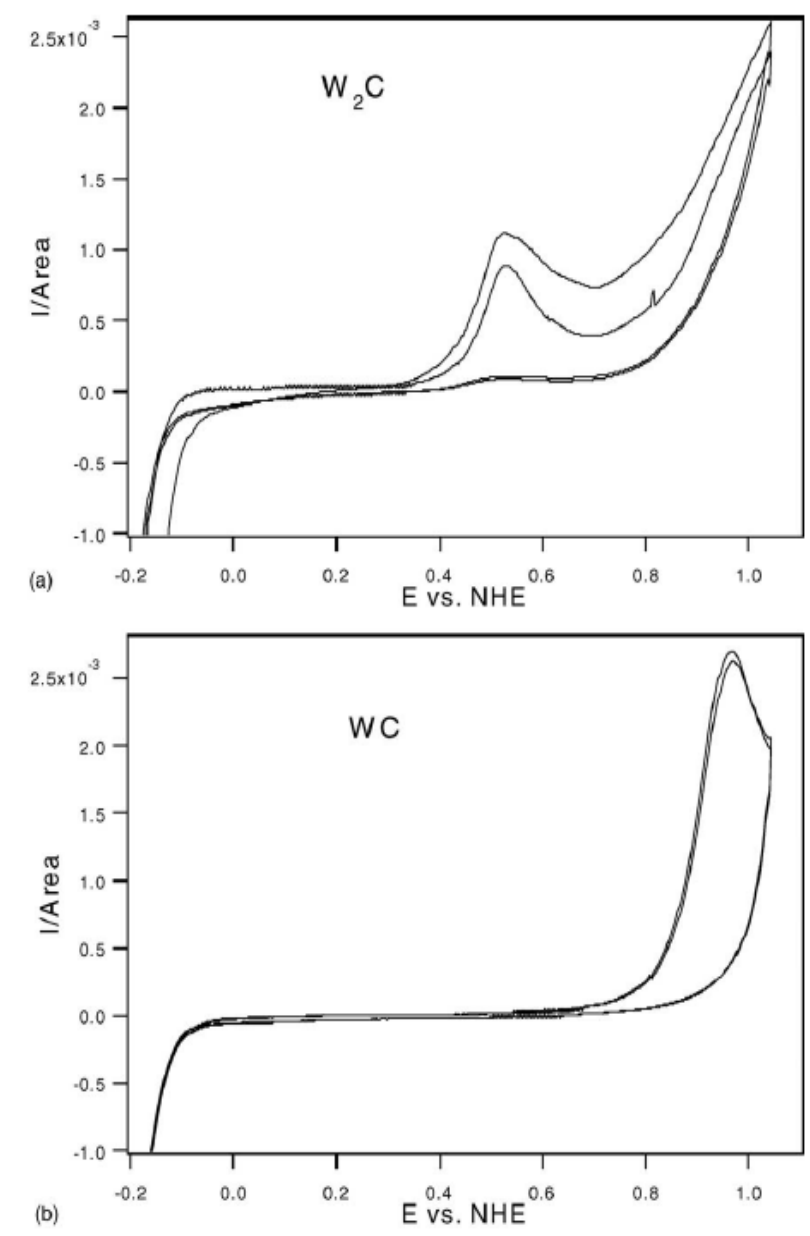

A thin layer of $\mathrm{WO}_{3}$ covers WC surface upon exposure to air, as confirmed by XPS [68]. The electrochemical dissolution of $\mathrm{WO}_{3}$ layers (less than $5 \mathrm{~nm}$ ) in electrolytes depends on the various electrochemical conditions such as the $\mathrm{pH}$ of the electrolyte and applied potential of the electrochemical system. The electrochemical dissolution was observed by different mechanisms at the basic [69] and acidic $\mathrm{pH}[70]$ of electrolyte. $\mathrm{WO}_{3}$ is readily dissolved as $\mathrm{WO}_{4}{ }^{2-}$ by surrounding ions in the electrolyte 
under alkaline conditions. Under acidic conditions, thin passive $\mathrm{WO}_{3}$ layers were preserved well on tungsten carbide surface [71]. It is believed that this layer could play a role as a corrosion protecting layer and inhibitor of electroactivities. Thus, WC can maintain electrochemical stability in acidic media, and can be applied to low temperature fuel cells operating in acidic condition of $\mathrm{pH}<2$. WC covered with thin $\mathrm{WO}_{3}$ layers were stable until $+0.7 \mathrm{~V}$ (vs SCE) without any redox current in $0.1 \mathrm{M} \mathrm{H}_{2} \mathrm{SO}_{4}$ electrolyte [72]. Further, the electrochemical stability on WC can be improved in acidic electrolyte by addition of second metals like Co [73,74], Ni [74], Fe [74] and Ta [75].

As shown in Figure 3, the electrochemical stability of pure and Pt modified WC foil has been studied before and after $\mathrm{CV}$ with XPS analysis [76]. Pure WC was completely changed to $\mathrm{W}_{\mathrm{x}} \mathrm{O}_{\mathrm{y}}$ species during 70 repeated $\mathrm{CV}$ cycles from $-0.09 \mathrm{~V}$ to $1.241 \mathrm{~V}$ (vs NHE) performed in $0.05 \mathrm{M} \mathrm{H}_{2} \mathrm{SO}_{4}$ electrolyte. However, in case of Pt modified WC, WC phases were conserved well after 50 cycles CV measurement. This enhanced electrochemical stability was also observed in CV results. The corrosion current density of Pt modified WC was dramatically reduced at the anodic corrosion region. In addition, onset potential of corrosion of Pt modified WC was observed at $\sim 1.0 \mathrm{~V}$, higher than that of pure WC at $\sim 0.8 \mathrm{~V}$ (vs NHE). Furthermore, this research group studied the electrochemical stability of pure and $\mathrm{Pt}$ modified $\mathrm{Mo}_{2} \mathrm{C}$ foil with same analysis. Unlike WC, the electrochemical stability of $\mathrm{Pt}$ modified $\mathrm{Mo}_{2} \mathrm{C}$ was not enhanced by $\mathrm{Pt}$. However, the $\mathrm{Mo}_{2} \mathrm{C}$ phase remained intact after $\mathrm{CV}$ measurement carried out at acidic media [76]. This result implies that $\mathrm{Mo}_{2} \mathrm{C}$ has the intrinsic stability without aid of other metals, and the onset potential for corrosion was $\sim 0.3 \mathrm{~V}$ (vs NHE).

Figure 3. (a) Electrochemical CV measurements and (b,c) XPS results of pure and Pt modified WC foil performed in $0.05 \mathrm{M} \mathrm{H}_{2} \mathrm{SO}_{4}$ electrolyte (Reprinted from Reference 76 with permission).
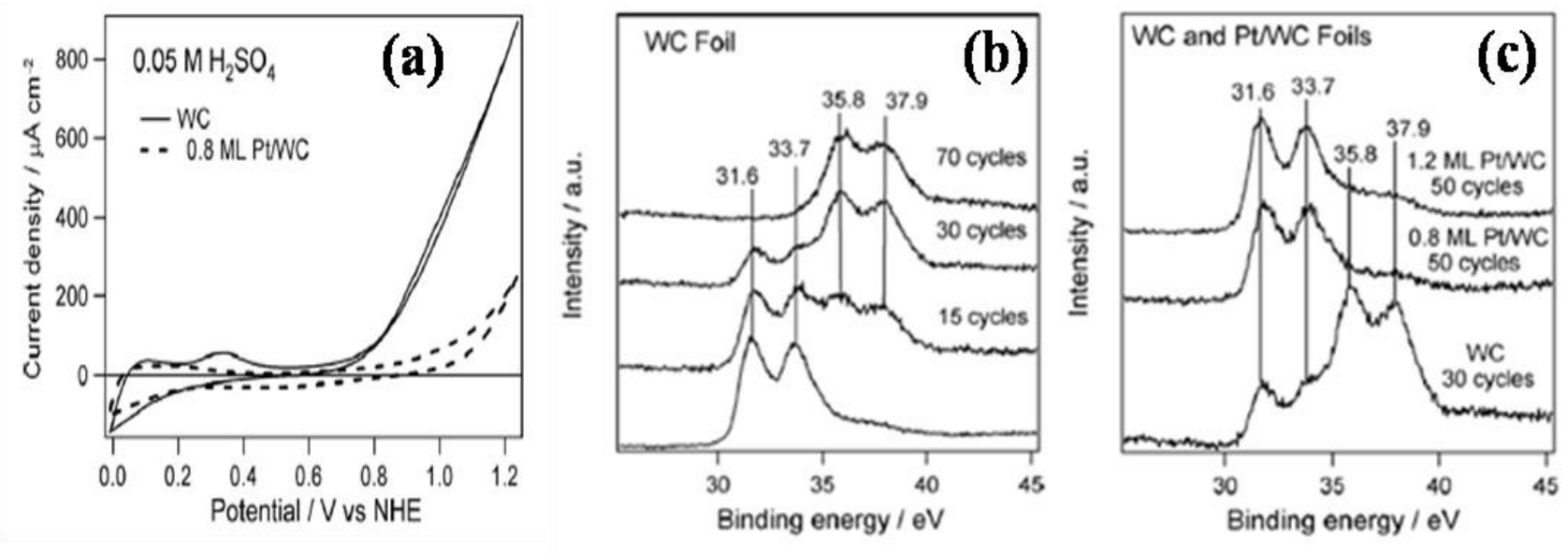

\subsection{CO Oxidation on TMCs}

Carbon monoxide $(\mathrm{CO})$ is produced as an intermediate during the oxidation of methanol in DMFC. Also, $\mathrm{CO}$ is the common impurity in the hydrogen feed in PEMFC systems. CO has a strong binding energy on Pt surface, poisoning the active sites of platinum. It needs to be oxidized to be removed from the sites. Tungsten carbide has shown high CO tolerance in low temperature fuel cell system. Thus, $20 \mathrm{wt} \% \mathrm{Pt} / \mathrm{WC}$ based on commercial tungsten carbide (low specific surface area $\sim 1 \mathrm{~m}^{2} / \mathrm{g}$ ) was reported 
for $\mathrm{CO}$ tolerance [77]. $\mathrm{CO}$ oxidation peak in $\mathrm{CO}$-stripping experiment with $\mathrm{Ag} / \mathrm{AgCl}$ reference electrode and a scan rate of $15 \mathrm{mV} / \mathrm{sec}$ in $1 \mathrm{M} \mathrm{HClO}_{4}$ electrolyte, appeared at $0.68 \mathrm{~V}$ (vs RHE) which was lower potential than that of $20 \mathrm{wt} \% \mathrm{Pt} / \mathrm{C}(0.8 \mathrm{~V}$ vs RHE). This result implies that WC could adsorb the hydroxyl group $(-\mathrm{OH})$ more easily like common second metals such as $\mathrm{Ru}$ and $\mathrm{Sn}$ in anode of DMFC. Therefore, $\mathrm{CO}$ adsorbed on $\mathrm{Pt}$ can be oxidized by $-\mathrm{OH}$ groups and leave the Pt surface. Pure WC and cobalt containing WC showed high current density in a half cell test under $1 \% \mathrm{CO} / 99 \% \mathrm{H}_{2}$ flow as shown in Figure 4 [78].

Figure 4. CO tolerance test of (a) pure WC, (b) Co containing WC (Reprinted from Reference 78 with permission).

(a)

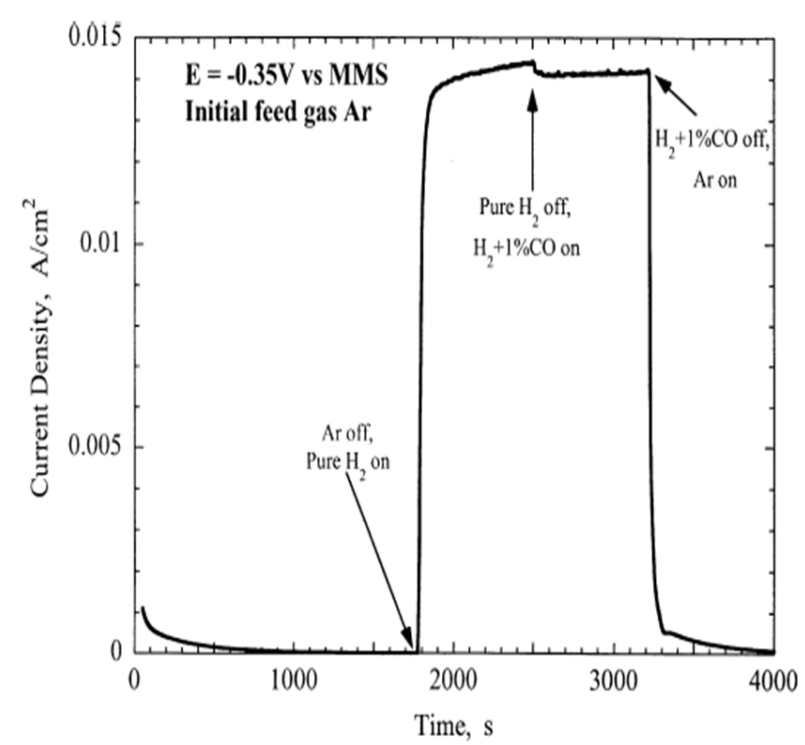

(b)

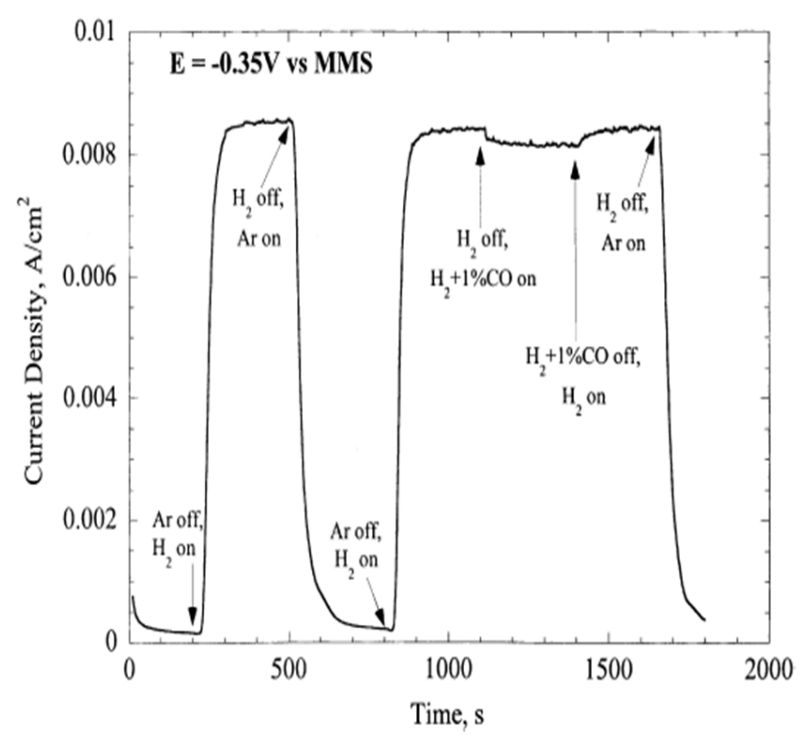

The difference of current density was just 2 6\% with and without CO. Also, $7.5 \mathrm{wt} \% \mathrm{Pt} / \mathrm{WC}$ electrocatalyst showed the $7 \%$ decrease of EAS value in a half cell system under $1 \% \mathrm{CO} / 99 \% \mathrm{H}_{2}$ gas dissolved in $1 \mathrm{M} \mathrm{H}_{2} \mathrm{SO}_{4}$ electrolyte (Figure 5) [79].

Considering the $20 \%$ decrease of commercial $\mathrm{Pt} / \mathrm{C}$ catalyst under the same condition, WC is considered to have the high resistance to $\mathrm{CO}$ poisoning. Another theory for $\mathrm{CO}$ tolerance was proposed by Hwu et al. for WC [80,81]. They suggested that the CO tolerance might be originated from the lower $\mathrm{CO}$ desorption temperature on pure and Pt modified WC than that of pure Pt. The suggestion was based on the fact that $\mathrm{CO}_{2}$ was not detected by TPD during methanol oxidation on Pt modified C/W(111) surface.

Considering the $20 \%$ decrease of commercial $\mathrm{Pt} / \mathrm{C}$ catalyst under the same condition, WC is considered to have the high resistance to $\mathrm{CO}$ poisoning. Another theory for $\mathrm{CO}$ tolerance was proposed by Hwu et al. for WC [80,81]. They suggested that the CO tolerance might be originated from the lower CO desorption temperature on pure and Pt modified WC than that of pure Pt. The suggestion was based on the fact that $\mathrm{CO}_{2}$ was not detected by TPD during methanol oxidation on Pt modified C/W(111) surface. 
Figure 5. CO tolerance test of (a) $20 \mathrm{wt} \% \mathrm{Pt} / \mathrm{C}$ (E-Tek), (b) $7.5 \mathrm{wt} \% \mathrm{Pt} / \mathrm{WC}$ (Reprinted from Reference 79 with permission).
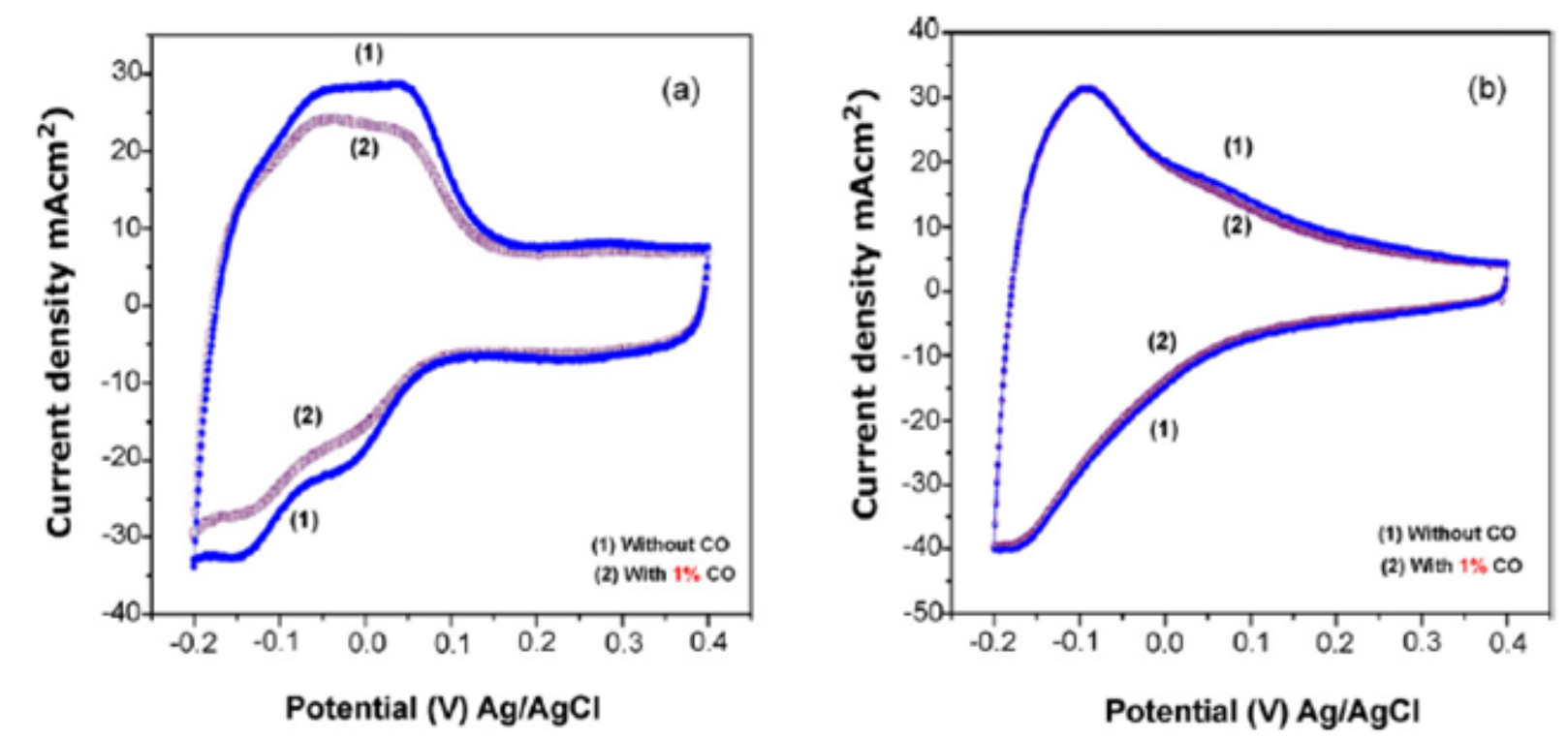

\subsection{Hydrogen Oxidation on TMCs}

Hydrogen oxidation over tungsten carbides provides the test for application to PEMFC. WC itself, metal loaded WC and carbon supported WC have displayed effective hydrogen oxidation showing a synergistic phenomenon of the corresponding components.

Hydrogen oxidation activity of pure $\mathrm{WC}$ and $\mathrm{W}_{2} \mathrm{C}$ phases was reported by Burstein et al. [67,78]. Pure WC showed anodic current density of $30 \mathrm{~mA} / \mathrm{cm}^{2}$ under $\mathrm{H}_{2}$ flow in chronoamperometric experiment in $1.5 \mathrm{M} \mathrm{H}_{2} \mathrm{SO}_{4}$ electrolyte. This anodic current density was three times higher than that of pure $\mathrm{W}_{2} \mathrm{C}$. In addition, WC loaded with a small amount of $\mathrm{Pt}$ was investigated for hydrogen oxidation. Electrocatalytic hydrogen oxidation activities can be represented by electrochemical active surface area (EAS $\left[\mathrm{m}^{2} / \mathrm{g}_{\mathrm{Pt}}\right]$ ) in half cell system. Ten wt $\% \mathrm{Pt}$ loaded WCs showed $5.9 \mathrm{~m}^{2} / \mathrm{g}_{\mathrm{Pt}}$ to $11.4 \mathrm{~m}^{2} / \mathrm{g}_{\mathrm{Pt}}$ in $0.5 \mathrm{M} \mathrm{H}_{2} \mathrm{SO}_{4}$ electrolyte at room temperature [82], while $7.5 \mathrm{wt} \% \mathrm{Pt}$ loaded $\mathrm{W}_{2} \mathrm{C}$ and $\mathrm{WC}$ led to high EAS value of $327 \mathrm{~m}^{2} / \mathrm{g}_{\mathrm{Pt}}$ [83] and $316 \mathrm{~m}^{2} / \mathrm{g}_{\mathrm{Pt}}$ [84] in $1 \mathrm{M} \mathrm{H}_{2} \mathrm{SO}_{4}$ electrolyte at room temperature.

Tungsten carbide based electrocatalysts without $\mathrm{Pt}$ have been evaluated in PEMFC single cell. The maximum power densities of WC/C $\left(1 \mathrm{mg} / \mathrm{cm}^{2}\right.$ loading on carbon paper) and $\mathrm{Ni}-\mathrm{WC} / \mathrm{C}\left(1 \mathrm{mg} / \mathrm{cm}^{2}\right.$ loading) were $6.5 \mathrm{~mW} / \mathrm{cm}^{2}$ and $8.9 \mathrm{~mW} / \mathrm{cm}^{2}$ measured for $5 \mathrm{~cm}^{2}$ of active area with cathode of $20 \mathrm{wt} \%$ Pt and Nafion 117 membrane [85]. Ni-WC/C showed $16 \mathrm{~mA} / \mathrm{cm}^{2}$ at $0.5 \mathrm{~V}$. In Figure 6, $\mathrm{W}_{2} \mathrm{C}$ (loading of $0.48 \mathrm{mg} / \mathrm{cm}^{2}$ ) based anode electrocatalyst prepared by ball-milling of $\mathrm{WO}_{3}, \mathrm{Mg}$ and $\mathrm{C}$ mixture was evaluated in PEMFC single cell test at $80{ }^{\circ} \mathrm{C}$ (cell operation temperature) for $5 \mathrm{~cm}^{2}$ of active area, cathode of $\mathrm{Pt} / \mathrm{C}\left(0.3 \mathrm{mg} / \mathrm{cm}^{2}\right)$, Nafion 112 and $\mathrm{H}_{2} /$ Air $=5$. This electrocatalyst showed high current densities of $240 \mathrm{~mA} / \mathrm{cm}^{2}$ (2 atm) and $280 \mathrm{~mA} / \mathrm{cm}^{2}$ (3 atm) at $0.5 \mathrm{~V}$, respectively [86]. The origin of this unusually high current density is not clear. 
Figure 6. Polarization curves of the tungsten carbide-based anode in a $5 \mathrm{~cm}^{2}$ single cell with fully humidified $\mathrm{H}_{2} /$ air at flow rates of $0.2 / 0.5 \mathrm{slpm}$ and $80{ }^{\circ} \mathrm{C}$ (Reprinted from Reference 86 with permission).

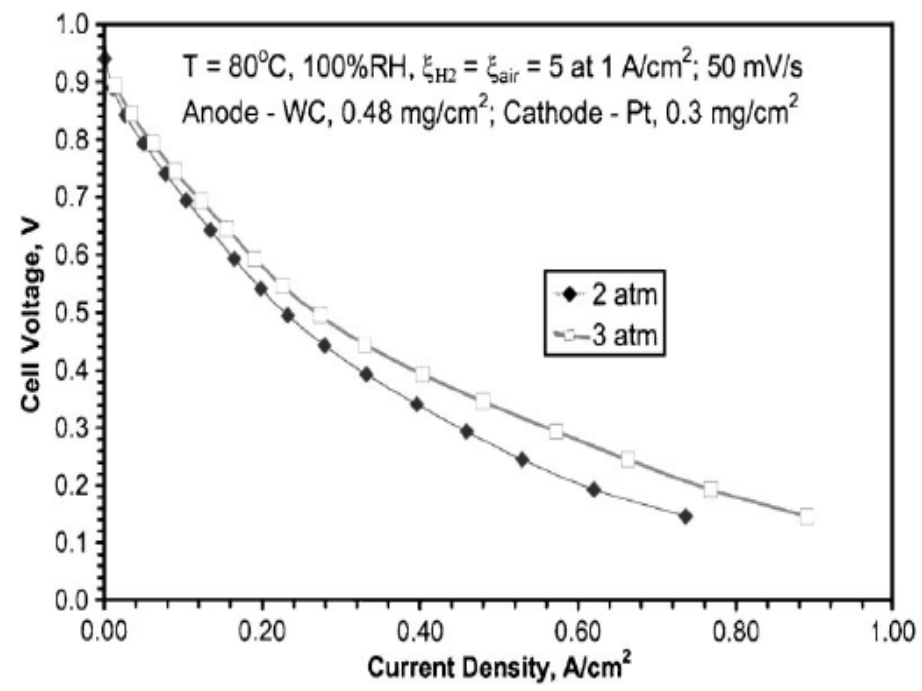

\subsection{Oxidation of Methanol and Ethanol on TMCs}

The electrocatalytic activity of methanol oxidation on pure tungsten carbide is very low [87]. Therefore, in many cases, the electroactivities for methanol oxidation was evaluated with a small amount of Pt loaded on tungsten carbides to take advantage of a synergistic effect between $\mathrm{Pt}$ and tungsten carbides [50,66,81]. These synergistic effects between Pt and C/W(111) and polycrystalline WC were revealed via TPD and HREELS analysis for methanol oxidation reaction. Tungsten carbides were more active for formation of methoxy group $\left(\mathrm{CH}_{3} \mathrm{O}-\right)$ than $\mathrm{Pt}$ as shown in Figure $7[66,81,88]$.

Figure 7. HREEL spectra monitoring thermal properties of $1.0 \mathrm{~L} \mathrm{CH}_{3} \mathrm{OD}$ adsorbed on (a) pure $\mathrm{C} / \mathrm{W}(111)$ and (b) $0.7 \mathrm{ML} \mathrm{Pt/C/W(111).} \mathrm{(Reprinted} \mathrm{from} \mathrm{Reference} 88$ with permission).
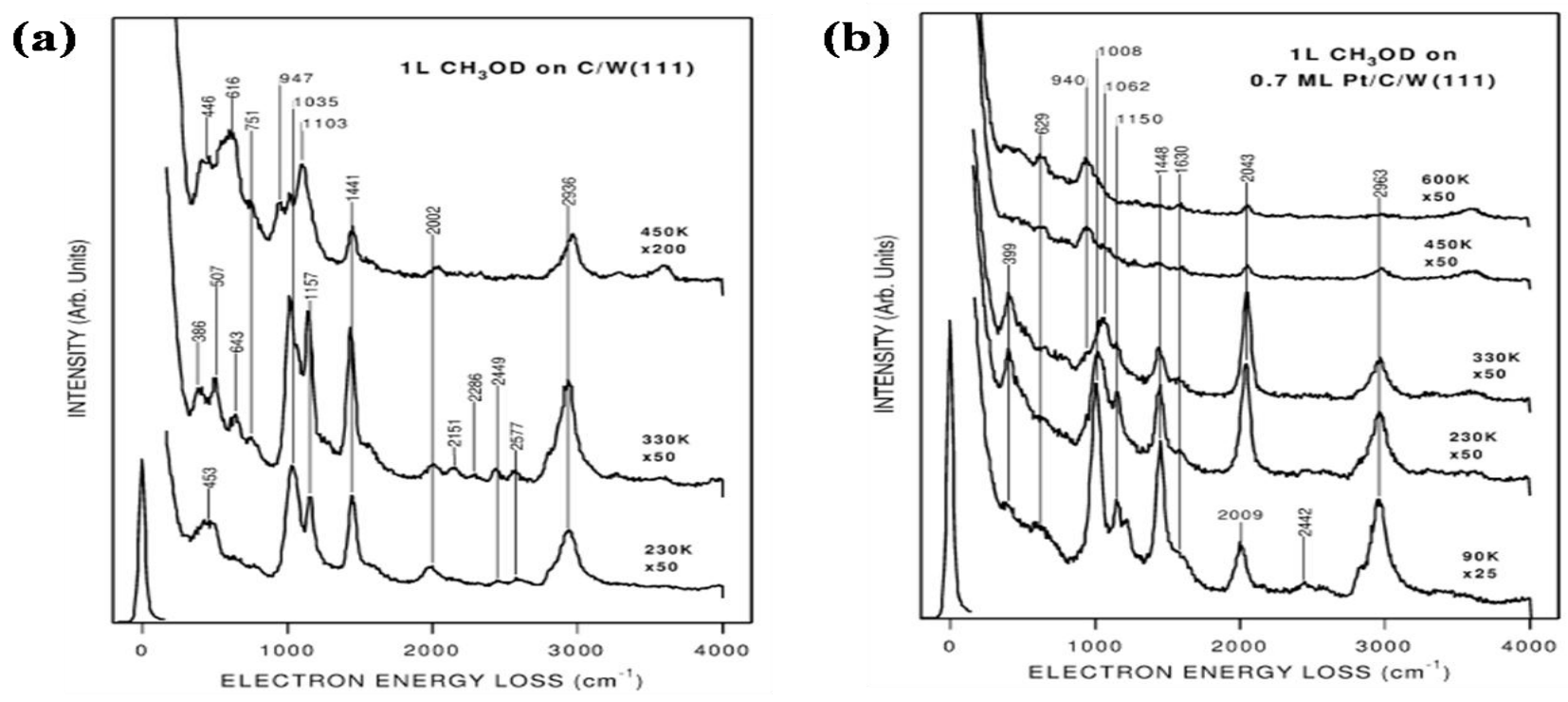
The methoxy groups adsorbed on pure $\mathrm{C} / \mathrm{W}(111)$ surface with energy loss of $2,936 \mathrm{~cm}^{-1}$ or $2,963 \mathrm{~cm}^{-1}$ were formed at very low temperature, and it remained up to high temperature without further reactions as in Figure 7(a). In contrast, Pt was more active for subsequent oxidation process of methoxy groups than tungsten carbides. As shown in Figure 7(b), the methoxy groups were actively oxidized by $0.7 \mathrm{ML} \mathrm{Pt} / \mathrm{C} / \mathrm{W}(111)$ from $330 \mathrm{~K}$ which was similar operating temperature of DMFC. Furthermore, they reported another type of synergistic effect related to the corrosion stability of tungsten carbide by addition of Pt [89].

These synergistic effects were also observed in other reports. $7.5 \mathrm{wt} \% \mathrm{Pt}$ loaded $\mathrm{W}_{2} \mathrm{C}$ microspheres partly covered with amorphous carbon led to high specific activity of $156 \mathrm{~mA} / \mathrm{cm}^{2}$ at $0.75 \mathrm{~V}$ (vs $\mathrm{Ag} / \mathrm{AgCl}$ ) for methanol oxidation in half cell test without $\mathrm{Ru}$ [83]. This specific activity was higher than that of commercial PtRu/C electrocatalyst. In addition to the synergistic effect for methanol oxidation discussed above, a strong bifunctional effect was suggested of $\mathrm{Pt}$ and WC for $\mathrm{CO}$ resistance. This group also reported that specific activities (above $200 \mathrm{~mA} / \mathrm{cm}^{2}$ at $0.75 \mathrm{~V}$ vs $\mathrm{Ag} / \mathrm{AgCl}$ ) of $3.5 \mathrm{wt} \%$ and $7.5 \mathrm{wt} \%$ loaded tungsten carbide (WC) were higher than those of $\mathrm{Pt} / \mathrm{W}_{2} \mathrm{C}$ and commercial catalyst (20 wt\% PtRu/C, E-Tek) for methanol oxidation as shown in Figure 8, [84].

Figure 8. (A) TEM images of (a) pure mesoporous $\mathrm{WC}$ and (b) $3.5 \mathrm{wt} \% \mathrm{Pt} / \mathrm{mesoporous}$ WC. (B) Methanol oxidation of (a) $3.5 \mathrm{wt} \% \mathrm{Pt} /$ part mesoporous WC, (b) $20 \mathrm{wt} \% \mathrm{PtRu} / \mathrm{C}$ commercial (E-Tek) and (c) $3.5 \mathrm{wt} \% \mathrm{Pt} / \mathrm{mesoporous} \mathrm{WC} \mathrm{in} \mathrm{repeated} \mathrm{CV} \mathrm{(Reprinted} \mathrm{from}$ Reference 84 with permission).
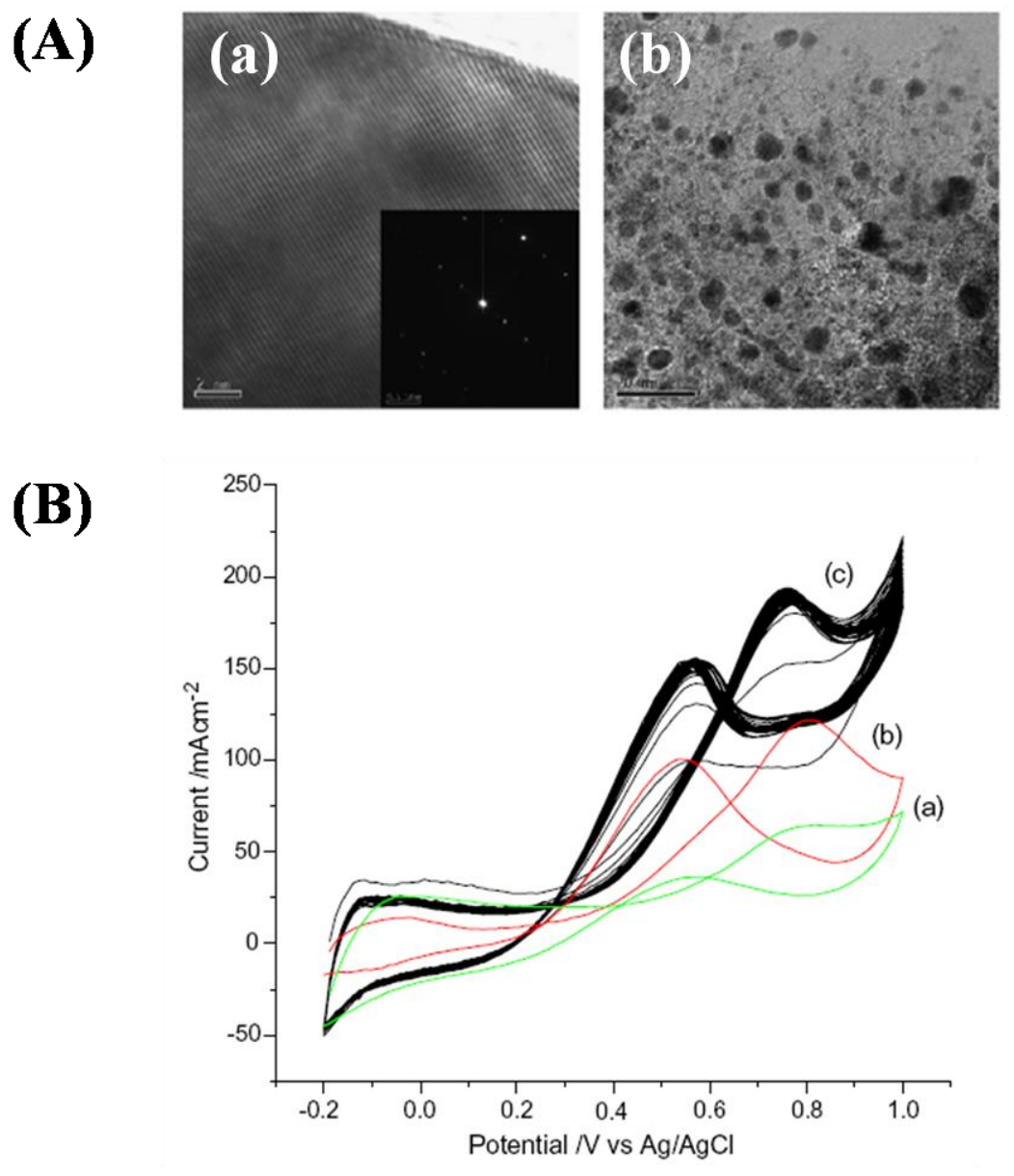
Also, $20 \mathrm{wt} \% \mathrm{Pt} / \mathrm{W}_{2} \mathrm{C}$ electrocatalysts showed the higher mass current density $\left(\mathrm{mA} / \mathrm{mg}_{\mathrm{Pt}}\right)$ than $20 \mathrm{wt} \% \mathrm{Pt} / \mathrm{C}$ at the same potential in $0.5 \mathrm{M} \mathrm{H}_{2} \mathrm{SO}_{4}$ electrolyte, SCE reference electrode [90]. Recently, many new reports for methanol oxidation over tungsten carbides have been published. $\mathrm{PtNiPb}$ loaded on WC (major phase) showed higher electroactivity and long-term stability than those of $\mathrm{PtNiPb} / \mathrm{C}$ in half cell reaction performed under $0.5 \mathrm{M} \mathrm{CH}_{3} \mathrm{OH}+0.5 \mathrm{M} \mathrm{H}_{2} \mathrm{SO}_{4}$ electrolyte and scan rate of $20 \mathrm{mV} / \mathrm{s}$ as shown in Figure 9 [91]. Particularly, the electroactivity of this electrocatalyst in CV was preserved for 1,000 cycles in potential range from 0.05 to $1.2 \mathrm{~V}$ (vs RHE). This enhanced activity and stability seemed to originate from the high $\mathrm{CO}$ tolerance and strong interaction between metals and tungsten carbide.

Figure 9. $\mathrm{CV}$ traces of methanol electro-oxidation on (A) $\mathrm{PtNiPb} / \mathrm{WC}$ and (B) $\mathrm{PtNiPb} / \mathrm{C}$ catalysts in a solution of $0.5 \mathrm{M} \mathrm{CH}_{3} \mathrm{OH}$ and $0.5 \mathrm{M} \mathrm{H}_{2} \mathrm{SO}_{4}$ before and after accelerated durability test (Reprinted from Reference 91 with permission).
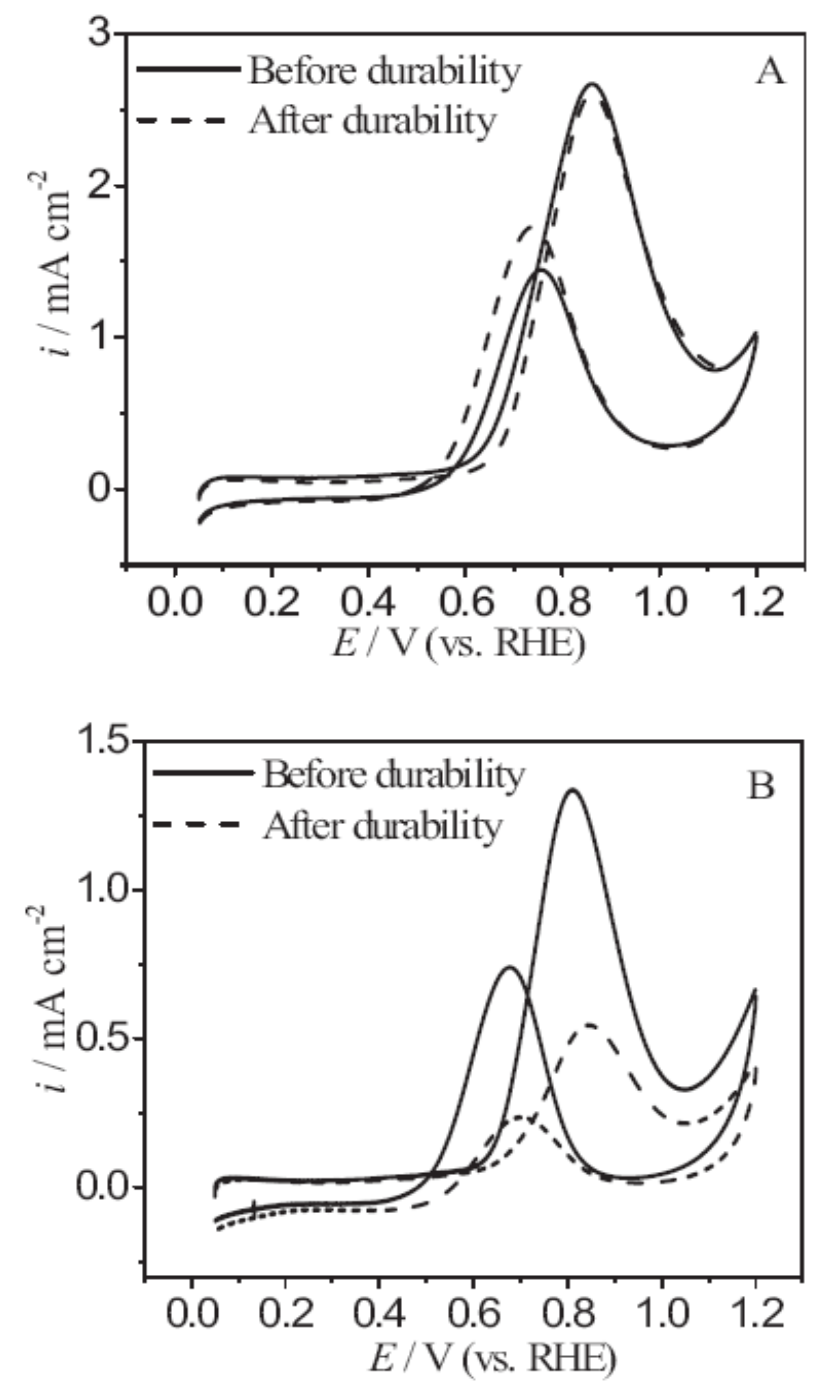

Also, PtWC/MWCNT showed higher current density for methanol oxidation in half cell evaluation than those of $\mathrm{PtRu} / \mathrm{C}$ and $\mathrm{Pt} / \mathrm{C}$ with stable operation for 1,000 cycles [92]. These effective results were also proposed to originate from the synergistic effect between $\mathrm{Pt}$ and $\mathrm{WC}$, high $\mathrm{CO}$ resistance from bifunctional effect of $\mathrm{Pt}$ and WC, and strong interaction between metal and WC. Pt decorated 
WC/graphitic carbon nanocomposite electrocatalyst showed excellent performance in half cell test in comparison with Pt loaded on Vulcan carbon (VC) [93]. The former electrocatalyst displayed more than three times higher mass electroactivity than that of $\mathrm{Pt} / \mathrm{VC}$ at forward peak potential, and $\mathrm{Pt} / \mathrm{WC} /$ graphitic carbon also showed higher stability for 3,000 CV cycles than Pt/VC.

Molybdenum carbides were studied for methanol oxidation by Chen et al. [94]. Methanol was readily dissociated on carbide-modified $\mathrm{Mo}(110)$ which was $63 \%$ of complete decomposition to atomic species $\left(\mathrm{C}\right.$ and $\mathrm{O}$ ) and $37 \%$ of gas product like $\mathrm{CO}$ and $\mathrm{H}_{2}$. This indicated that the molybdenum carbides could become a promoter of tungsten carbides for high electroactivity in DMFC system. And C/V(110) and $\mathrm{C} / \mathrm{Ti}(0001)$ surfaces could produce the methoxy intermediate with $\mathrm{CH}_{4}$ gas after dissociation of methanol as analyzed by TPD and HREELS techniques [95]. Especially, C/Ti(0001) surface showed the ability to decompose the methoxy groups at $351 \mathrm{~K}$ and $333 \mathrm{~K}$. C/V(110) and C/Ti(0001) surfaces were more active for methoxy formation than those of other planes.

For ethanol oxidation, non-Pt tungsten carbides electrocatalysts were investigated. Thus, $\mathrm{Pd} / \mathrm{W}_{2} \mathrm{C}$ on $\mathrm{C}$ and $\mathrm{Pd} / \mathrm{W}_{2} \mathrm{C}$ on MWCNT were tested in half cell system with $1 \mathrm{~mol} \mathrm{dm}{ }^{-3} \mathrm{KOH}+1 \mathrm{~mol} \mathrm{dm}^{-3}$ ethanol electrolyte and $\mathrm{Hg} / \mathrm{HgO}$ reference electrode under various operating temperatures as shown in Figure 10 [96].

Figure 10. (A) TEM images of (a) WC/MWCNT, (b, c) Pd-WC/MWCNT and (B) the half cell results of various electrocatalysts for ethanol oxidation (Reprinted from Reference 96 with permission).
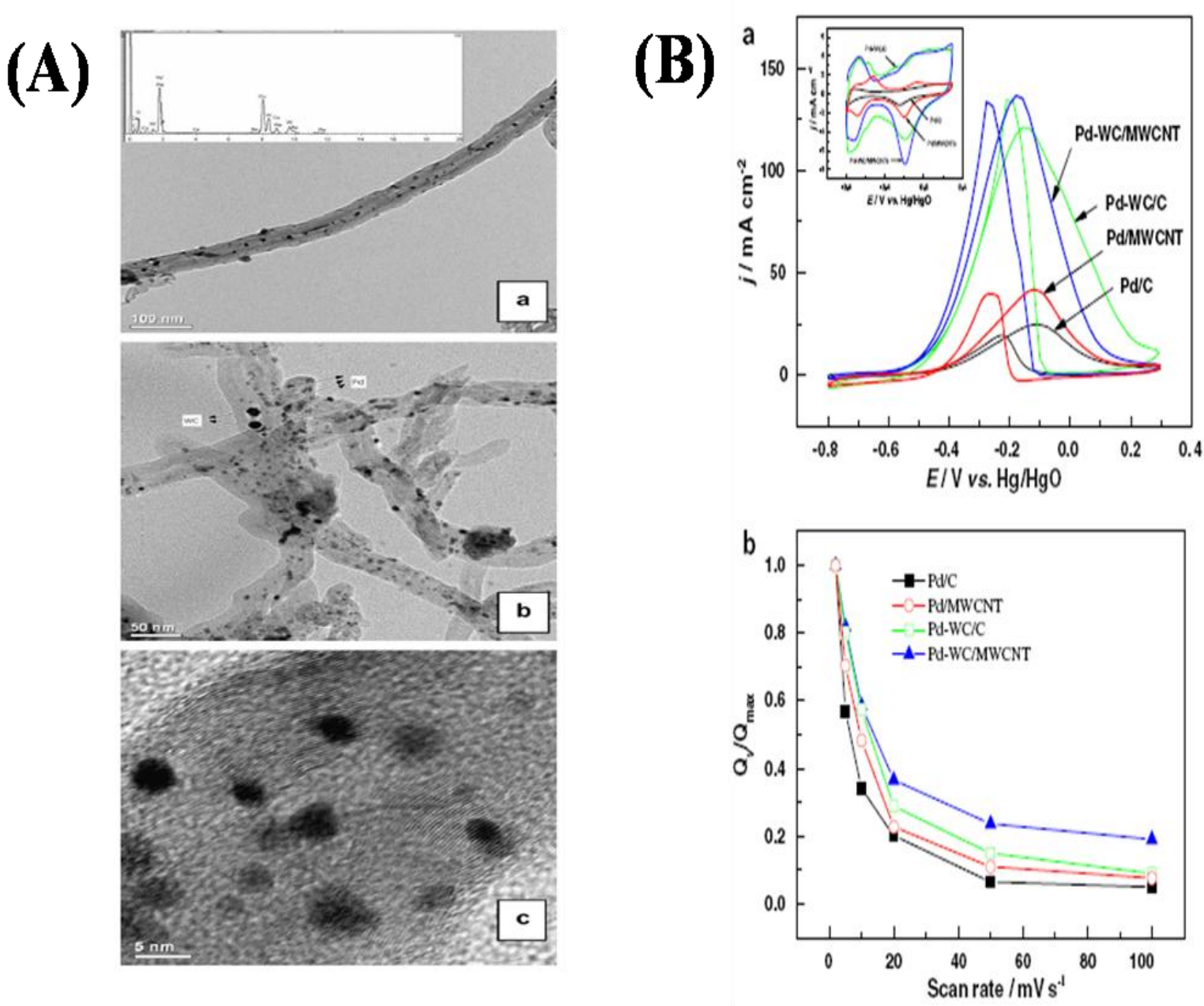
Similarly, $\mathrm{Pd} / \mathrm{WC}$ on $\mathrm{C}$ and $\mathrm{Pd} / \mathrm{WC}$ on MWCNT electrocatalysts also showed higher specific activities $\left(\mathrm{mA} / \mathrm{cm}^{2}\right)$ and exchange current density $\left(\mathrm{A} / \mathrm{cm}^{2}\right)$ than $\mathrm{Pd}$ on $\mathrm{C}$ and Pd on MWCNT for ethanol oxidation, respectively. Especially, Pd/WC electrocatalysts showed two orders of magnitude higher exchange current density than that of $\mathrm{Pd} / \mathrm{C}$ between $303 \mathrm{~K}$ and $363 \mathrm{~K}$. AuPd-WC/C (mixed phase of tungsten carbides: $\mathrm{WC}+\mathrm{W}_{2} \mathrm{C}+\mathrm{W}$ ) displayed higher specific activity than those of $\mathrm{Pt} / \mathrm{C}$ and $\mathrm{Au}-\mathrm{Pd} / \mathrm{C}$ under the same electrochemical condition [97].

There are some encouraging results of alcohol oxidation with TMC-based electrocatalysts. It is particularly interesting that the combination of a minute amount Pt or even Pd and TMC gives activities comparable to that of $\mathrm{Pt} / \mathrm{C}$ of high loading. Thus the synergistic effect between the se metals and TMC is remarkable although its origin is sometimes not clear. However, these encouraging results have not been demonstrated under more realistic single cell conditions.

\subsection{Oxygen Reduction on TMCs}

Metal-loaded carbides and carbide-metal co-deposited carbon have been employed for ORR. Tungsten carbides have been most widely studied for oxygen reduction reaction among TMCs.

$40 \mathrm{wt} \% \mathrm{Pt} / \mathrm{WC}$ showed similar cathodic current $\left(-5 \times 10^{-4} \mathrm{~A}\right)$ to that of $40 \mathrm{wt} \% \mathrm{Pt} / \mathrm{C}$ as well as the electrochemical stability during 100 cycles in CV from $0 \mathrm{~V}$ to $1.4 \mathrm{~V}$ (vs RHE) with 2,000 rpm [98]. The electroactivity of $40 \mathrm{wt} \% \mathrm{Pt} / \mathrm{C}$ for oxygen reduction was seriously degraded after 100 cycles. By contrast, $40 \mathrm{wt} \% \mathrm{Pt} / \mathrm{WC}$ electrocatalyst maintained stable cathodic current under the same operation condition. The WC+Ta electrode resulted in the enhanced cathodic onset potential, current density and stability at various temperatures [75]. This electrocatalysts showed $0.8 \mathrm{~V}$ of onset potential and $-33 \mu \mathrm{A} / \mathrm{cm}^{2}$ (at $0.2 \mathrm{~V}$ vs DHE) of cathodic current density for ORR. These high electrochemical properties seemed to originate from the enhanced stability of WC by Ta addition. The onset potential and current density were higher than those of WC, Ta-WC, Ta, TaC.

Figure 11. (a) TEM images and (b) half cell results for oxygen reduction (Reprinted from Reference 99 with permission).

(a)

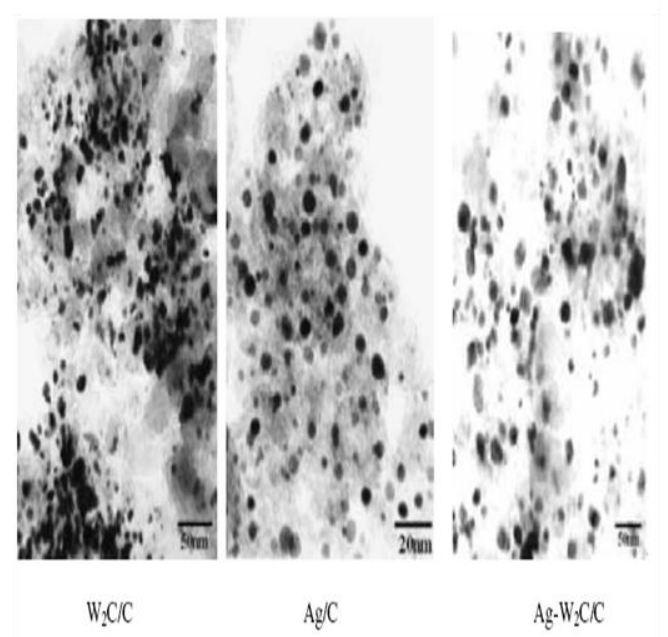

(b)

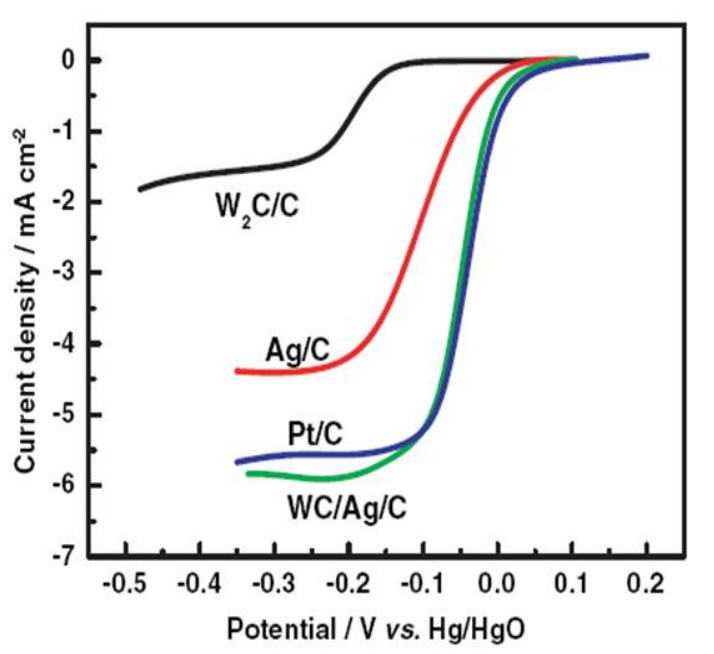


As other active tungsten carbide based electrocatalysts, $\mathrm{Ag}-\mathrm{W}_{2} \mathrm{C} / \mathrm{C}$ (Figure 11) [99], $\mathrm{Pt}-\mathrm{W}_{2} \mathrm{C}(+\mathrm{WC}) / \mathrm{C}$ [100], AuPd-WC/C [101] showed higher cathodic onset potential, current density and Tafel slopes including higher exchange current density than those of $\mathrm{Pt}$ metal or $\mathrm{Pt} / \mathrm{C}$, which are state-of-the-art cathodic electrocatalyst. Especially, $\mathrm{Pt}-\mathrm{W}_{2} \mathrm{C}(+\mathrm{WC}) / \mathrm{C}$ showed much better methanol resistance than $\mathrm{Pt} / \mathrm{C}$ at cathode side of DMFC as shown in Figure 12. Only oxidation current was observed when methanol concentration was above $0.2 \mathrm{M}$, whereas reduction current was observed up to $0.5 \mathrm{M}$. Thus higher concentrations of methanol feed could be used as fuel.

Figure 12. (A) $\mathrm{CVs}$ of $\mathrm{ORR}$ on $\mathrm{Pt} / \mathrm{C}$ in an $\mathrm{O}_{2}$ saturated $0.5 \mathrm{M} \mathrm{H}_{2} \mathrm{SO}_{4}$ solution with different methanol concentrations (B) $\mathrm{CVs}$ of $\mathrm{ORR}$ on $\mathrm{Pt}-\mathrm{W}_{2} \mathrm{C} / \mathrm{C}$ at the same conditions (Reprinted from Reference 100 with permission).
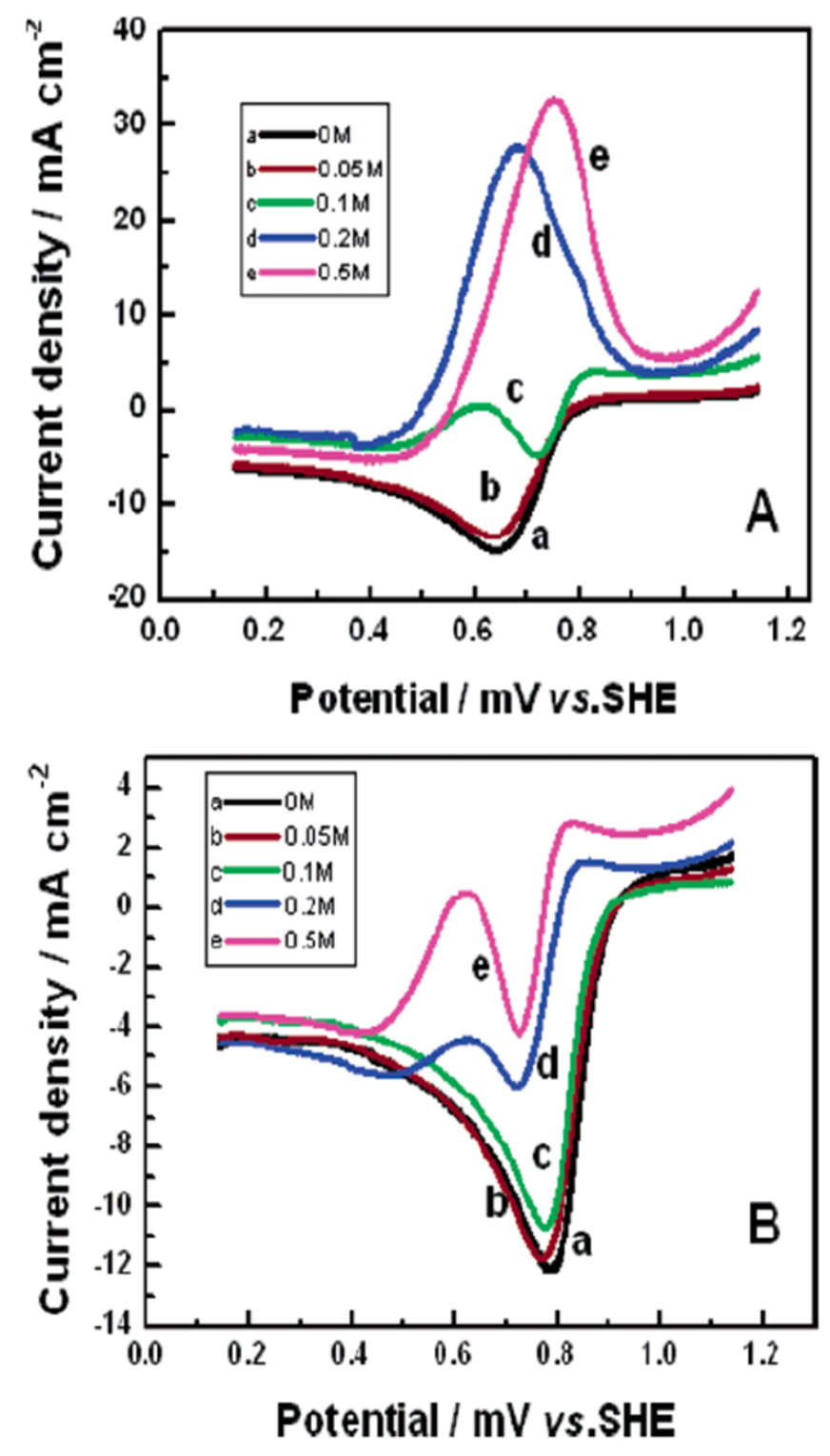

Like the previous oxidation reactions, all reports are based on results obtained only from the half cell system. There is no good single cell performance reported for tungsten carbides based electrocatalysts. 
It should be noted that the results of half-cell test are not necessarily transferable to the results of the single cell test.

\section{Transition Metal nitrides (TMNs)}

Transition metal nitrides (TMNs) display the similar formation and physicochemical properties including catalysis to those of transition metal carbides (TMCs) [102]. All transition metals can form nitrides with the exception of the second and third row Group 8-10 metals ( $\mathrm{Ru}, \mathrm{Os}, \mathrm{Rh}, \mathrm{Ir}, \mathrm{Pd}$, and Pt). Table 3 provides important nitrides for Group 4-10 metals and the formation of mixed and alloy nitrides is already indicated in Table 2. They also have high melting points, hardness, and corrosion resistance. These physical properties are desired attributes of catalytic materials that require resistance against attrition and sintering under reaction conditions. TMNs demonstrate catalytic advantages over their parent metals in activity, selectivity, and resistance to poisoning. They are good catalysts for various reactions typically catalyzed by noble metals of high cost and limited supply. The catalytic properties of TMNs have been reviewed together with those of carbides due to their resemblance in many reactions [51-55] and references that cover more general physicochemical properties of the materials are also available [56,58-60,62,103,104].

Table 3. Transition metal nitrides and their positions in the periodic table.

\begin{tabular}{|c|c|c|c|c|c|c|}
\hline Group 4 & Group 5 & Group 6 & Group 7 & Group 8 & Group 9 & Group 10 \\
\hline $\begin{array}{c}\mathrm{Ti}_{2} \mathrm{~N} \\
\mathrm{TiN}_{09} \\
\mathrm{TiN}\end{array}$ & $\begin{array}{l}\mathbf{V}_{2} \mathbf{N} \\
\mathbf{V N}\end{array}$ & $\begin{array}{c}\mathrm{Cr}_{2} \mathrm{~N} \\
\mathrm{CrN}\end{array}$ & $\begin{array}{l}\mathrm{Mn}_{4} \mathrm{~N} \\
\mathrm{Mn}_{2} \mathrm{~N} \\
\mathrm{Mn}_{3} \mathrm{~N}_{2}\end{array}$ & $\begin{array}{l}\mathrm{Fe}_{4} \mathrm{~N} \\
\mathrm{Fe}_{2} \mathrm{~N}\end{array}$ & $\begin{array}{l}\mathrm{Co}_{3} \mathrm{~N} \\
\mathrm{Co}_{2} \mathrm{~N}\end{array}$ & $\mathrm{Ni}_{3} \mathrm{~N}$ \\
\hline $\mathrm{ZrN}$ & $\begin{array}{c}\mathrm{Nb}_{4} \mathbf{N}_{3} \\
\mathrm{Nb}_{2} \mathbf{N} \\
\mathrm{NbN} \\
\mathrm{NbN}_{0.95}\end{array}$ & $\begin{array}{c}\mathrm{Mo}_{2} \mathbf{N} \\
\mathrm{MoN}\end{array}$ & $\mathrm{TcN}_{0.75}$ & & & \\
\hline $\begin{array}{c}\mathbf{H f}_{3} \mathbf{N}_{2} \\
\mathbf{H f N}\end{array}$ & $\begin{array}{c}\mathrm{Ta}_{3} \mathbf{N}_{5} \\
\mathrm{Ta}_{2} \mathbf{N} \\
\mathrm{TaN} \\
\mathrm{TaN}_{0.8} \\
\mathrm{TaN}_{0.1}\end{array}$ & $\begin{array}{l}\mathbf{W}_{2} \mathbf{N} \\
\mathbf{W N}\end{array}$ & $\mathbf{R e}_{2} \mathbf{N}$ & & & \\
\hline
\end{tabular}

The composition of TMNs is similar to that of TMCs of the same metal. TMNs of Group 4-6 are thermodynamically more stable and catalytically more active than parent metals. Here, the nitrogen resides in the interstitial sites formed by the larger parent metal atoms. The thermodynamic stability decreases with increasing Group number from the nitrides of the Group 4 metals. Because the size of atoms decreases with the group number, the lattice of high group metals cannot accommodate interstitial nitrogen atoms while maintaining close-packed or near close-packed metal atoms [102]. Thus, nitrides of Group 7-10 metals are generally less stable and do not belong to the interstitial compounds. The catalysis of these nitrides is not discussed, although these metals often turn to surface or bulk 
nitrides during reactions involving nitrogen-containing reactants. Non metallic Group 13, 14 nitrides $\left(\mathrm{BN}, \mathrm{Si}_{3} \mathrm{~N}_{4}, \mathrm{AlN}, \mathrm{GaN}\right.$, and $\left.\mathrm{InN}\right)$ are characterized by predominantly covalent bonding and are nonconductive or semiconductive. Non metallic Group 13, 14 nitrides have also displayed the similar properties with metallic nitrides such as high melting temperature, hardness and corrosion resistance. The catalytic utilization of non-metallic nitrides is limited, but they could be used as catalyst supports.

The physicochemical properties of TMNs are similar to those of TMCs. However, the difference in the number of valence electron between nitrogen and carbon brings some different properties [102]. In general, the shift in structure correlates with the number of valence electrons in carbon and nitrogen, and suggests that these elements increase the concentration of $s p$ electrons in their alloys. And the change of geometric and electronic structure is closely related with catalysis. A maximum melting point of metals is observed between Group 5 and 6. In case of TMCs, the maximum temperatures of TMCs and TMNs are shifted to Group 5 and Group 4, respectively [55]. The shift in the carbides and nitrides again correlates with the number of valence electrons in carbon and nitrogen and suggests a greater degree of band-filling in the compounds.

The band structure of TMNs is qualitatively similar to those of fcc transition metals in the shape and relative ordering of the bands. For the transition metals, the $d$-band begins to fill from $\mathrm{Ru}$ and $\mathrm{Os}$ to $\mathrm{Pd}$ and Pt. This coincidence of the band structure seems responsible for the observed similarity in catalytic properties between Group 4-6 TMCs and TMNs and the Group 8-10 transition metals [102]. The electronic structure strongly related with properties of TMNs studied by various spectroscopic techniques [105]. Thus, the filled states of $d$-band were narrowed after formation of nitrides, resulting in the similar electronic structure of TMCs and noble metals up to the Fermi level. On the other hand, at energies above the Fermi level, the width of the unfilled states of the metal was found to be broadened because of the TMNs formation, giving rise to a greater density of empty levels for TMNs than those of the parent metal. Due to the deficiency in the $d$-band occupation near the Fermi level, nitride surfaces could have a reduced ability to donate $d$-electrons to adsorbates. Therefore, high reactivities of early transition metals are explained by the formation of nitrides for reactions involving the donation of electrons from the metal catalysts to absorbate. The broadened unfilled portion of the $d$-band should make these nitrides better electronic acceptors than both the parent metals and the Pt Group metals. Thus for reactions that involve the donation of bonding electrons to the unfilled orbitals of the metal substrate, nitride catalysts might be more efficient than both parent metals and Pt Group metals [102].

\subsection{Electrochemical Stability of TMNs}

Application of TMNs has been attempted for the electrochemical systems, including fuel cells, electric storage and secondary battery as electrocatalysts with low cost and high efficiency, although not as much as TMCs. Recently, various investigations have reported on TMNs as electrocatalyst in some important fields, and the attention has been growing. Almost all electrochemical systems depended heavily on the large amount of noble metals such as $\mathrm{Pt}$, which makes them expensive. As mentioned, TMNs has been considered as a promising electrocatalyst to replace the noble materials due to their unique catalytic properties, low price, and abundance. As before, electrochemical stability is one of important considerations of electrochemical properties for long-term stability in real system. 
Tungsten mono-nitride (WN) showed anodic current at low anodic potential region around $-0.4 \mathrm{~V}$ (vs $\mathrm{Hg} / \mathrm{HgO}$ ) in voltammogram performed with a scan rate of $10 \mathrm{mV} / \mathrm{s}$ in alkaline electrolyte (1 $\mathrm{M} \mathrm{KOH}$ ), which could easily provide the anions to WN [106]. The onset anodic potential representing the electrochemical corrosion of $\mathrm{WN}$ was shifted to the lower potential region, and the corrosion current increased by decrease of scan rate. Until now, the information of electrochemical stability for tungsten nitride is insufficient.

Molybdenum nitride was used in low temperature fuel cells as cathodic electrocatalyst. $\mathrm{Mo}_{\mathrm{x}} \mathrm{N}$ ( $\mathrm{x}=1$ or 2 ) on Ti substrate displayed electrochemical stability in acidic electrolyte of $4.4 \mathrm{M} \mathrm{H}_{2} \mathrm{SO}_{4}$ up to $+0.67 \mathrm{~V}$ (vs SHE) anodic potential during repeated 50 cycles [107]. But, this electrocatalysts showed the surface damage such as crack and crumbling in high cathodic (below $-0.1 \mathrm{~V}$ vs SHE) and anodic (above $+0.67 \mathrm{~V}$ vs SHE) potential region due to the cathodic and anodic corrosion, respectively. Especially, at high anodic potential region above $+0.67 \mathrm{~V}$ (vs SHE), the composition of oxygen increased due to oxide formation of $\mathrm{MoO}_{\mathrm{x}}$, which could cause deactivation. These results indicate that $\mathrm{Mo}_{\mathrm{x}} \mathrm{N}$ reacts with oxygen species present in the aqueous electrolyte and it is unstable above $+0.67 \mathrm{~V}$ (vs SHE).

Titanium nitride (TiN) shows the high corrosion resistance in electrochemical system. TiN on glass substrate had the corrosion onset potential of $+0.6 \mathrm{~V}$ (vs SSE) in $0.5 \mathrm{M} \mathrm{H}_{2} \mathrm{SO}_{4}$ electrolyte [108]. This result indicates that TiN is stable up to $+0.6 \mathrm{~V}$ (vs SSE) without electrochemical redox reaction. And, TiN showed enhanced onset potential ( $\sim 3 \mathrm{~V}$ vs SHE) for corrosion than that of TiC ( +2 V vs SHE) in $\sim 3 \mathrm{M} \mathrm{NaNO}_{3}$ electrolyte carried out with a scan rate of $0.5 \mathrm{~V} / \mathrm{s}$ [109]. Therefore, TiN has been utilized as coating of other materials for enhanced corrosion resistance [110].

\subsection{Methanol Oxidation on TMNS}

As stated above, the application of TMNs for methanol oxidation is rare. In one case, Pt loaded TiN showed the electroactivity for methanol oxidation [111]. As shown in Figure 13, Pt/TiN deposited on stainless steel substrate showed the high $\mathrm{I}_{\mathrm{f}} / \mathrm{I}_{\mathrm{b}}$ ratio representing the high $\mathrm{CO}$ resistance in voltammogram performed with a scan rate of $20 \mathrm{mV} / \mathrm{sec}$ in $0.5 \mathrm{M} \mathrm{CH}_{3} \mathrm{OH}+0.5 \mathrm{M} \mathrm{H}_{2} \mathrm{SO}_{4}$ electrolyte. The bifunctional effect between $\mathrm{Pt}$ and TiN was cited for the $\mathrm{CO}$ resistance of $\mathrm{Pt} / \mathrm{TiN}$. 
Figure 13. (a) SEM image and (b) Cyclic voltammograms of Pt-TiN for methanol oxidation in $0.5 \mathrm{M} \mathrm{CH}_{3} \mathrm{OH}$ and $0.5 \mathrm{M} \mathrm{H}_{2} \mathrm{SO}_{4}$ obtained by repeated cycles (Reprinted from Reference 111 with permission).

\section{(a)}

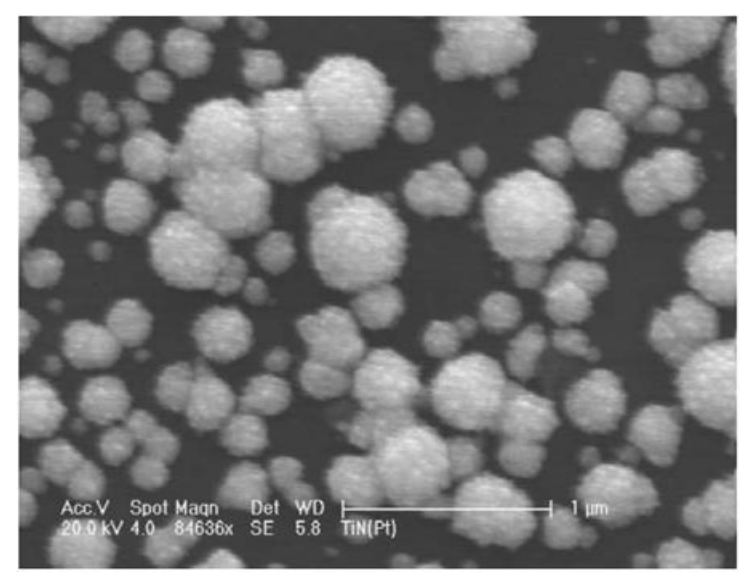

(b)

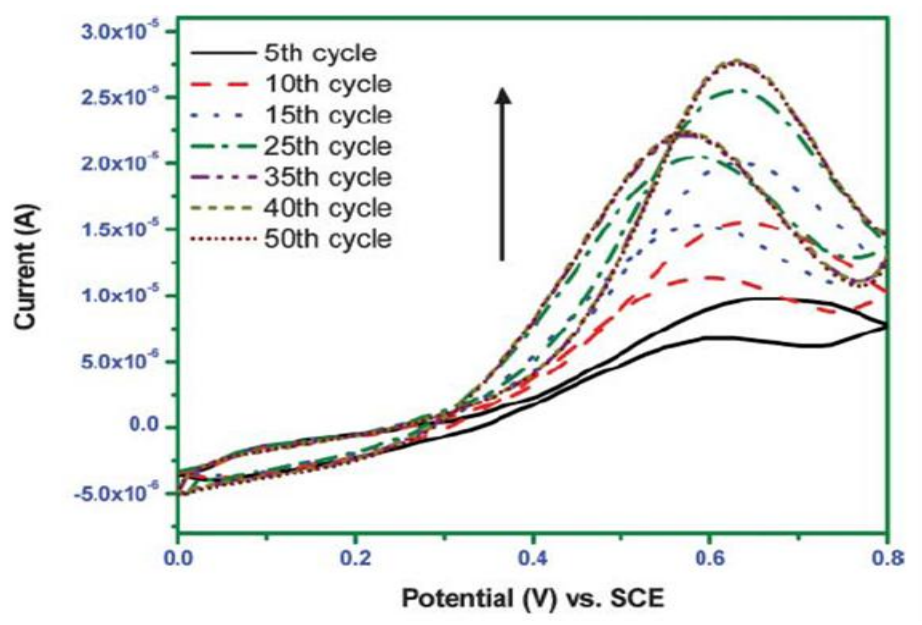

\subsection{Oxygen Reduction on TMNs}

$\mathrm{W}_{2} \mathrm{~N} / \mathrm{C}$ was investigated under half and single cell PEMFC conditions for oxygen reduction [112]. $\mathrm{W}_{2} \mathrm{~N} / \mathrm{C}(18 \mathrm{wt} \% \mathrm{~W})$ displayed effective electroactivity for oxygen reduction in voltammogram shown in Figure 14 performed with oxygen saturated $0.5 \mathrm{M}$ sulfuric acid electrolyte. In contrast, this electrocatalyst did not show the cathodic current in nitrogen saturated electrolyte. Furthermore, in single cell PEMFC test, the maximum power density of $\mathrm{W}_{2} \mathrm{~N} / \mathrm{C}$ cathode loaded on carbon paper $\left(0.644 \mathrm{mg} / \mathrm{cm}^{2}\right)$ was $\sim 40 \mathrm{~mW} / \mathrm{cm}^{2}$ under cell temperature of $80^{\circ} \mathrm{C}$. In this single cell test, the anode side employed $46.2 \mathrm{wt} \% \mathrm{Pt} / \mathrm{C}$ catalyst with loading of $0.3 \mathrm{mg}_{\mathrm{Pt}} / \mathrm{cm}^{2}$. For long-term stability, the chronopotentiometry in single cell condition displayed stable potential for $80 \mathrm{hrs}$ without deactivation under fixed current density of $120 \mathrm{~mA} / \mathrm{cm}^{2}$.

The electroactivity for oxygen reduction reaction (ORR) of carbon supported MoN (with no other metal electrocatalyst) was reported as shown in Figure 15 [113]. MoN/C showed the high cathodic current corresponding to ORR in half cell test carried out in $5 \mathrm{M}$ methanol $+0.5 \mathrm{M} \mathrm{H}_{2} \mathrm{SO}_{4}$ electrolyte. This result indicates that MoN/C electrocatalyst might show the high reactivity for oxygen reduction in cathode side. Also, $18 \mathrm{wt} \% \mathrm{Mo}_{2} \mathrm{~N} / \mathrm{C}$ electrocatalyst was evaluated for ORR in real PEMFC system [114]. The single cell evaluation was carried out at $80{ }^{\circ} \mathrm{C}$ with $46.2 \mathrm{wt} \% \mathrm{Pt} / \mathrm{C}$ catalyst $\left(0.3 \mathrm{mg}_{\mathrm{Pt}} / \mathrm{cm}^{2}\right)$ at anode side. The maximum power density was $65 \mathrm{~mW} / \mathrm{cm}^{2}$ and $50 \mathrm{~mW} / \mathrm{cm}^{2}$ for $0.609 \mathrm{mg} / \mathrm{cm}^{2}$ and $1.165 \mathrm{mg} / \mathrm{cm}^{2}$ loading of $\mathrm{Mo}_{2} \mathrm{~N} / \mathrm{C}$ on carbon paper, respectively. The long-term stability was also studied by chronopotentiometric results recorded in single cell condition at a fixed current density of $200 \mathrm{~mA} / \mathrm{cm}^{2}$. There was no deactivation of cell performance for $60 \mathrm{hrs}$. The results are encouraging considering no other additional metals have been added, and further study is warranted. 
Figure 14. (a) Polarization curves at different cell temperatures of the single cell with the $\mathrm{W}_{2} \mathrm{~N} / \mathrm{C}$ as the cathode catalyst. (b) Stability test at the constant current density (Reprinted from Reference 112 with permission).

(a)

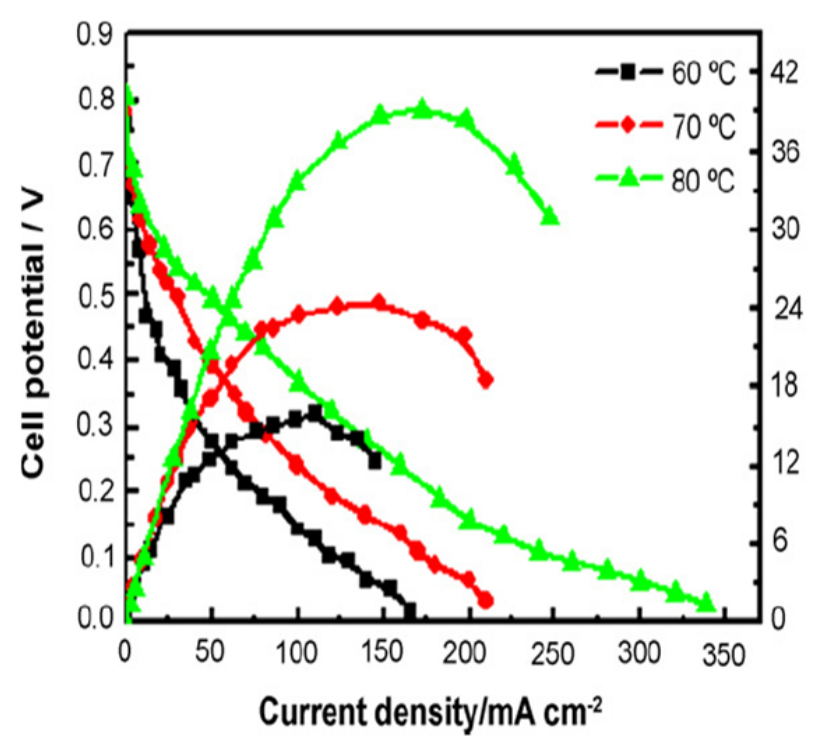

(b)

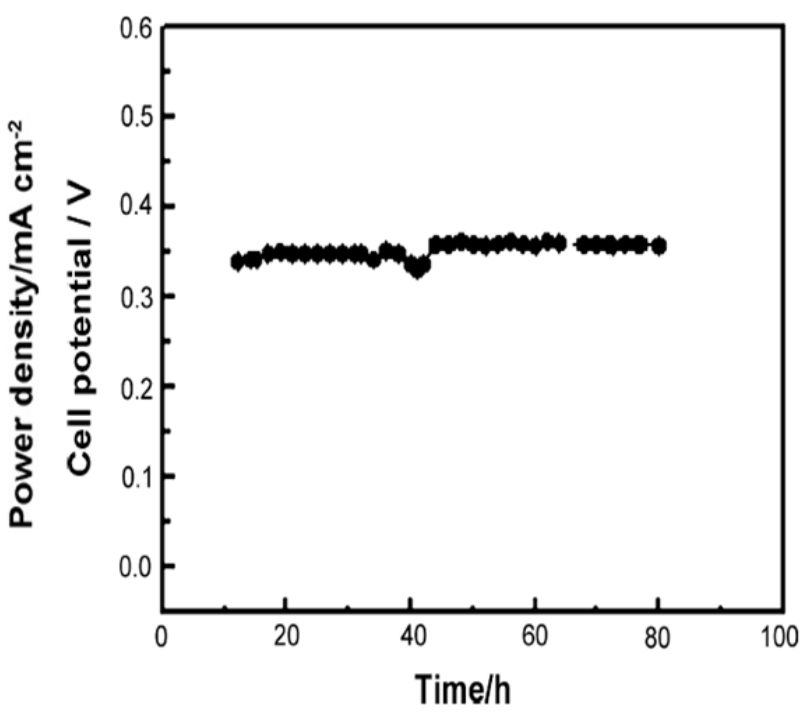

Figure 15. (A) Cell polarization curves of single cells with different cathode catalysts cathode: (a) $18 \mathrm{wt} \% \mathrm{Mo}_{2} \mathrm{~N} 0.609 \mathrm{mg} / \mathrm{cm}^{2}$; (b) $18 \mathrm{wt} \% \mathrm{Mo}_{2} \mathrm{~N} 1.165 \mathrm{mg} / \mathrm{cm}^{2}$. (B) Stability study for the $\mathrm{Mo}_{2} \mathrm{~N} / \mathrm{C}$ electrocatalyst cathode: $18 \mathrm{wt} \% \mathrm{Mo}_{2} \mathrm{~N} 0.609 \mathrm{mg} / \mathrm{cm}^{2}$. (Reprinted from Reference 113 with permission).

(A)

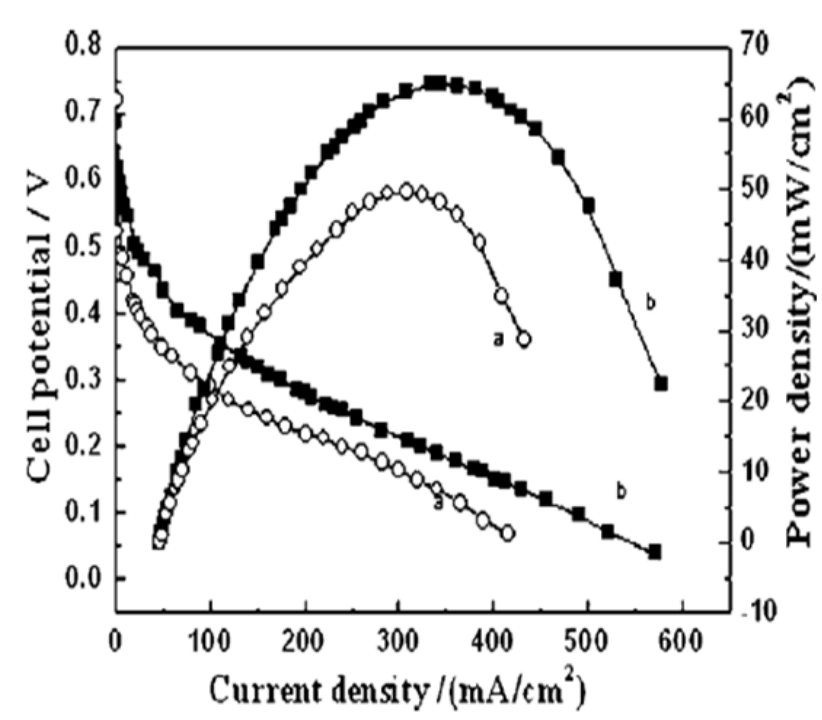

(B)

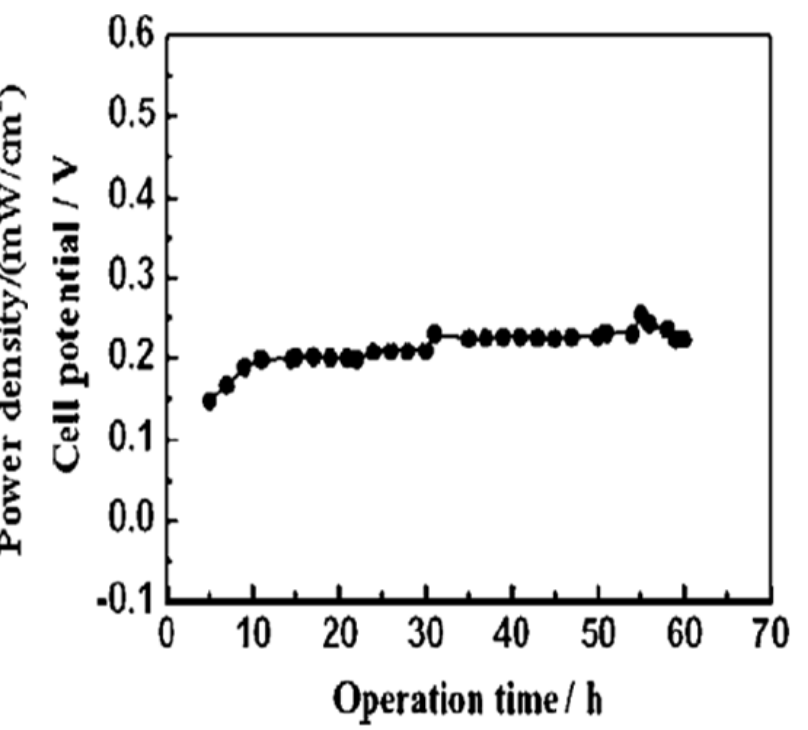

\section{Conclusions}

Transition metal carbides (TMCs) and nitrides (TMNs) have been extensively investigated for applications in energy devices as electrode materials such as low temperature fuel cells. TMCs seem to 
suit for low temperature fuel cell application according to the results of such studies as well as their electrocatalytic properties. TMCs have desired properties as electrodes for low temperature fuel cells like surface reactivity resembling Pt, electrochemical stability, high CO resistance and interaction with metals. Yet its own activity is low by itself. Therefore, TMCs are employed as support or second active component combining with other metals such as $\mathrm{Pt}, \mathrm{Ru}$ and $\mathrm{Pd}$ for high electrochemical activities. When TMCs is combined with other metals, the electrocatalytic synergistic phenomena are often observed. The new electrocatalysts based on TMCs combined with non-Pt and minute amount of Pt for low temperature fuel cells could give new materials combinations of high performance and low cost. Further extension to single metal/bimetal/ternary metals including the structural and electronic modification could be a fruitful approach together with the modification of TMCs itself such as bimetallic carbides.

TMNs have attracted attention in the field of ORR for low temperature fuel cell. TMNs has been also utilized for ORR in combination with other metals such as Pt and Pd with effective half and single cell performances. Actually, the possibility of TMNs for ORR seems to be higher than TMCs. TMNs has been known for promotion of the 4-electron pathway, and enhancement of stability via strong interaction with various metals. Furthermore, the long-term stabilities are already demonstrated in some cases. Like TMCs, modification and variation of metals as well as nitrides could provide opportunity to find new electrode materials.

\section{Acknowledgements}

This work has been supported by Hydrogen R\&D Center sponsored by the Ministry of Science and Technology, and BK-21 program sponsored the Ministry of Education.

\section{References and Notes}

1. Yu, J.; Matsuura, T.; Yoshikawa, Y.; Islam, M.N.; Hori, M. In Situ analysis of performance degradation of a PEMFC under nonsaturated humidification. Electrochem. Solid State Lett. 2005, 8, A156-A158.

2. Mehta, V.; Cooper, J.S. Review and analysis of PEM fuel cell design and manufacturing. J. Power Sources 2003, 113, 32-53.

3. Borup, R.; Meyers, J.; Pivovar, B.; Kim, Y.S.; Mukundan, R.; Garland, N.; Myers, D.; Wilson, M.; Garzon, F.; Wood, D.; Zelenay, P.; More, K.; Stroh, K.; Zawodinski, T.; Boncella, J.; McGrath, J.E.; Inaba, M.; Miyatake, K.; Hori, M.; Ota, K.; Ogumi, Z.; Miyata, S.; Nishikata, A.; Siroma, Z.; Uchimoto, Y.; Yasuda, K.; Kimijima, K.; Iwashita, N. Scientific aspects of polymer electrolyte Fuel Cell durability and degradation. Chem. Rev. 2007, 107, 3904-3951.

4. Steele, B.C.H.; Heinzel, A. Materials for fuel-cell technologies. Nature 2001, 414, 345-352.

5. Carrette, L.; Friendrich, K.A.; Stimming, U. Fuel cells: Principles, types, fuels, and applications. Chemphyschem 2000, 1, 162-193.

6. Wilson, M.S.; Garzon, F.H.; Sickafus, K.E.; Gottesfeld, S. Surface area loss of supported platinum in polymer electrolyte fuel cells. J. Electrochem. Soc. 1993, 140, 2872-2877.

7. Barnett, B.M.; Teagan, W.P. The role of fuel cells in our energy future. J. Power Sources 1992, 37, 15-31. 
8. Melle, F.D. The global and urban environment: the need for clean power systems. J. Power Sources 1998, 71, 7-11.

9. Bruijn, F.D. The current status of fuel cell technology for mobile and stationary applications. Green Chem. 2005, 7, 132-150.

10. Shao, Y.; Yin, G.; Wang, Z.; Gao, Y. Proton exchange membrane fuel cell from low temperature to high temperature: Material challenges. J. Power Sources 2007, 167, 235-242.

11. Aricoa, A.S.; Srinivasanb, S.; Antonuccia, V. DMFCs: From fundamental aspects to technology development. Fuel Cells 2001, 1, 133-161.

12. Carrette, L.; Friendrich, K.A.; Stimming, U. Fuel cells-Fundamentals and applications. Fuel Cells 2001, 1, 5-39.

13. Gasteiger, H.A.; Kocha, S.S.; Sompalli, B.; Wagner, F.T. Activity benchmarks and requirements for Pt, Pt-alloy, and non-Pt oxygen reduction catalysts for PEMFCs. Appl. Catal. B. 2005, 56, 9-35.

14. Litster, S.; McLean, G. PEM fuel cell electrodes. J. Power Sources 2004, 130, 61-76.

15. Bernardi, D.M.; Verbrugge, M.K. A mathematical model of the solid-polymer-electrolyte. $J$. Electrochem. Soc. 1992, 139, 2477-2491.

16. Bensebaa, F.; Farah, A.A.; Wang, D.; Bock, C.; Du, X.; Kung, J.; Page, Y.L. Microwave synthesis of polymer-embedded Pt-Ru catalyst for direct methanol fuel cell. J. Phys. Chem. B 2005, 109, 15339-15344.

17. Li, Q.; He, R.; Jensen, J.O.; Bjerrum, N.J. Approaches and recent development of polymer electrolyte membrane for fuel cells operating above $100{ }^{\circ} \mathrm{C}$. Chem. Mater. 2003, 15, 4896-4915.

18. Alberti, G.; Casciola, M. Composite membranes for medium-temperature PEM fuel cells. Аnnu. Rev. Mater. Res. 2003, 33, 129-154.

19. Herring, A.M. Inorganic-polymer composite membranes for proton exchange membrane fuel cells. J. Macromol. Sci. Part C 2006, 46, 245-296.

20. Liu, H.; Songa, C.; Zhang, L.; Zhang, J.; Wang, H.; Wilkinson, D.P. A review of anode catalysis in the direct methanol fuel cell. J. Power Sources 2006, 155, 95-110.

21. Arico, A.S.; Bruce, P.; Scrosati, B.; Tarascon, J.; Schalkwijk, W. Nanostructured materials for advanced energy conversion and storage devices. Nat. Mater. 2005, 4, 366-377.

22. Zhou, J.; Zhou, X.; Sun, X.; Li, R.; Murphy, M.; Ding, Z.; Sun, X.; Sham, T. Interaction between Pt nanoparticles and carbon nanotubes-An X-ray absorption near edge structures (XANES) study. Chem. Phys. Lett. 2007, 437, 229-232.

23. Faubert, G.; CGti, R.; Dodelet, J.P.; Lefevre, M.; Bertrand, P. Oxygen reduction catalysts for polymer electrolyte fuel cells from the pyrolysis of $\mathrm{Fe}$ acetate adsorbed on 3,4,9,10-perylenetetracarboxylic dianhydride. Electrochim. Acta 1999, 44, 2589-2603.

24. Jaouen, F.; Marcotte, S.; Dodelet, J.; Lindbergh, G. Oxygen reduction catalysts for polymer electrolyte fuel cells from the pyrolysis of iron acetate adsorbed on various carbon supports. $J$. Phys. Chem. B 2003, 107, 1376-1386.

25. Bashyam, R.; Zelenay, P. A class of non-percious metal composite catalysts for fuel cells. Nature 2006, 443, 63-66. 
26. Yuasa, M.; Yamaguchi, A.; Itsuki, H.; Tanaka, K.; Yamamoto, M.; Oyaizu, K. Modifying carbon particles with polypyrrole for adsorption of cobalt ions as electrocatatytic site for oxygen reduction. Chem. Mater. 2005, 17, 4278-4281.

27. Serov, A.; Kwak, C. Review of non-platinum anode catalysts for DMFC and PEMFC application. Appl. Catal. B. 2009, 90, 313-320.

28. Smotkin, E.S.; Diaz-Morales, R.R. New electrocatalysts by combinatorial methods. Annu. Rev. Mater. Res. 2003, 33, 557-579.

29. Zhang, L.; Zhang, J.; Wilkinson, D.P.; Wang, H. Progress in preparation of non-noble electrocatalysts for PEM fuel cell reactions. J. Power Sources 2006, 156, 171-182.

30. Fournier, J.; Faubert, G.; Tilquin, J.Y.; Cote, R.; Guay, D.; Dodelet, J.R. High-performance, low Pt content catalysts for the electrorecluction of oxygen in polymer-electrolyte fuel cells. $J$. Electrochem. Soc. 1997, 144, 145-154.

31. Vante, N.A.; Jaegermann, W.; Tributsch, H.; Honle, W.; Yvod, K. Electrocatalysis of oxygen reduction by chalcogenides containing mixed transition metal clusters. J. Am. Chem. Soc. 1987, 109, 3251-3257.

32. Matter, P.H.; Zhang, L.; Ozkan, U.S. The role of nanostructure in nitrogen-containing carbon catalysts for the oxygen reduction reaction. J. Catal. 2006, 239, 83-96.

33. Serov, A.A.; Min, M.; Chai, G.; Han, S.; Kang, S.; Kwak, C. Preparation, characterization, and high performance of RuSe/C for direct methanol fuel cells. J. Power Sources 2008, 175, 175-182.

34. Mustain, W.E.; Kepler, K.; Prakash, J. Investigations of carbon-supported $\mathrm{CoPd}_{3}$ catalysts as oxygen cathodes in PEM fuel cells. Electrochem. Commun. 2006, 8, 406-410.

35. Ye, S.; Vijh, A.K.; Dao, L.H. Oxygen reduction on a new electrocatalyst based on highly porous carbonized polyacrylonitrile microcellular foam with very low platinum loading. J. Electroanal. Chem. 1996, 415, 115-121.

36. Hu, F.P.; Shen, P.K. Ethanol oxidation on hexagonal tungsten carbide single nanocrystal-supported Pd electrocatalyst. J. Power Sources 2007, 173, 877-881.

37. Helia, H.; Jafariana, M.; Mahjania, M.G.; Gobalb, F. Electro-oxidation of methanol on copper in alkaline solution. Electrochim. Acta 2004, 49, 4999-5006.

38. Joo, S.H.; Choi, S.J.; Oh, I.; Kwak, J.; Liu, Z.; Terasaki, O.; Ryoo, R. Ordered nanoporous arrays of carbon supporting high dispersions of platinum nanoparticles. Nature 2001, 412, 169-172.

39. Fujimoto, T.; Terauchi, S.; Umehara, H.; Kojima, I.; Henderson, W. Sonochemical preparation of single-dispersion metal nanoparticles from metal salts. Chem. Mater. 2001, 13, 1057-1060.

40. Boxall, D.L.; Deluga, G.A.; Kenik, E.A.; King, W.D.; Lukehart, C.M. Rapid synthesis of a $\mathrm{Pt}_{1} \mathrm{Ru}_{1} /$ Carbon nanocomposite using microwave irradiation: A DMFC anode catalyst of high relative performance. Chem. Mater. 2001, 13, 891-900.

41. Bensebaa, F.; Patrito, N.; Page, Y.L.; L'Ecuyer, P.; Wang, D. Tunable platinum-ruthenium nanoparticle properties using microwave synthesis. J. Mater. Chem. 2004, 14, 3378-3384.

42. Jalan, V.; Taylor, E.J. Importance of interatomic spacing in catalytic reduction of oxygen in phosphoric acid. J. Electrochem. Soc. 1983, 130, 2299-2302.

43. Bessel, C.A.; Laubernds, K.; Rodriguez, N.M.; Baker, R.T.K. Graphite Nanofibers as an electrode for fuel cell applications. J. Phys. Chem. B 2001, 105, 1115-1118. 
44. Wang, C.; Waje, M.; Wang, X.; Tang, J.M.; Haddon, R.C.; Yan, Y. Proton exchange membrane fuel cells with carbon nanotube based electrodes. Nano Lett. 2004, 4, 345-348.

45. Gasteiger, H.A.; Panels, J.E.; Yan, S.G. Dependence of PEM fuel cell performance on catalyst loading. J. Power Sources 2004, 127, 162-171.

46. Mukerjee, S.; Srinivasan, S.; Soriaga, M.P. Role of structural and electronic properties of Pt and Pt alloys on electrocatalysis of oxygen reduction. J. Electrochem. Soc. 1995, 142, 1409-1422.

47. Shao, Y.; Yin, G.; Gao, Y. Understanding and approaches for the durability issues of Pt-based catalysts for PEM fuel cell. J. Power Sources 2007, 171, 558-566.

48. Christian, J.B.; Smith, S.P.E.; Whittingham, M.S.; Abruna, H.D. Tungsten based electrocatalyst for fuel cell applications. Electrochem. Commun. 2007, 9, 2128-2132.

49. Levy, R.L.; Boudart, M. Platinum-like behavior of tungsten carbide in surface catalysis. Science 1973, 181, 547-549.

50. Lee, J.S.; Hyun, T.H. Metal carbides. In Encyclopedia of Catalysis, 1st ed.; Horvath, I.T., Ed.; John Wiley \& Sons: New York, NY, USA, 2003.

51. Storms, E.K. The Refractory Carbides; Academic Press: New York, NY, USA, 1967.

52. Toth, L.E. Transition Metal Carbides and Nitrides; Academic Press: New York, NY, USA, 1971.

53. Levi, R.B. Advanced Materials in Catalysis; Academic Press: New York, NY, USA, 1977.

54. Oyama, S.T. The Chemistry of Transition Metal Carbides and Nitrides; Blackie Academic and Professional: Glasgow, UK, 1996.

55. Gogotsi, Y.G.; Andrievski, R.A. Materials Science of Carbides, Nitrides and Borides; Kluwer Academic publisher: Dordrecht, The Netherlands, 1999.

56. Freer, R. The Physics and Chemistry of Carbide, Nitrides, and Borides; Kluwer Academic Publishers: Dordrecht, The Netherlands, 1990.

57. Gubanov, V.A.; Ianovsky, A.L.; Zhukov, V.P. Electronic Structure of Refractory Carbides and Nitrides; Cambridge University Press: Cambridge, UK, 1994.

58. Johansson, L.I.; Electronic and structural properties of transition-metal carbide and nitride surfaces. Surf. Sci. Rep. 1995, 21, 177-250.

59. Chen, J.G. NEXAFS investigations of transition metal oxides, nitrides, carbides, sulfides and other interstitial compounds. Surf. Sci. Rep. 1997, 30, 1-152.

60. Hwu, H.H.; Chen, J.G. Surface chemistry of transition metal carbides. Chem. Rev. 2005, 105, 185-212.

61. Oyama, S.T.; Kieffer, R. Kirk-Othmer Encyclopedia of Chemical Technology; John Wiley \& Sons: New York, NY, USA, 1992.

62. Ettmayer, P.; Lengauer, W. Encyclopedia of Inorganic Chemistry; John Wiley \& Sons: Chichester, UK, 1994.

63. Oyama, S.T. Preparation and catalytic properties of transition metal carbides and nitrides. Catal. Today 2007, 15, 179-200.

64. Chen, J.G. Carbide and nitride overlayers on early transition metal surfaces: Preparation, characterization, and reactivities. Chem. Rev. 1996, 96, 1477-1498.

65. Heine, V. s-d Interaction in transition metals. Phys. Rev. 1967, 153, 673-682. 
66. Zellner, M.B.; Chen, J.G. Surface science and electrochemical studies of $\mathrm{WC}$ and $\mathrm{W}_{2} \mathrm{C}$ PVD films as potential electrocatalysts. Catal. Today 2005, 99, 299-307.

67. Brady, C.D.A.; Rees, E.J.; Burstein, G.T. Electrocatalysis by nanocrystalline tungsten carbides and the effects of codeposited silver. J. Power Sources 2008, 179, 17-26.

68. Andersson, K.M.; Bergstrom, L. Oxidation and dissolution of tungsten carbide powder in water. Int. J. Refract. Mer. H. 2000, 18, 121-129.

69. Jain, M.; Sadangi, R.K.; Cannon, W.R.; Kear, B.H. Processing of functionally graded WC/Co/diamond nanocomposites. Scr. Mater. 2001, 44, 2099-2103.

70. Ghandehari, M.H. Anodic behavior of cemented WC-6\% Co alloy in phosphoric acid solutions. $J$. Eletrochem. Soc. 1980, 127, 2144-2147.

71. Binder, H.; Kohling, A.; Kuhn, W.; Lindner, W.; Sanstede, G. Nature 1969, 224, 1299-1300.

72. Patil, P.R.; Pawar, S.H.; Pail, P.S. The electrochromic properties of tungsten oxide thin films deposited by solution thermolysis. Sol. State Ionics 2000, 136, 505-511.

73. Sutthiruangwong, S.; Mori, G. Corrosion properties of Co-based cemented carbides in acidic solutions. Int. J. Refract. Met. H. 2003, 21, 135-145.

74. Scholl, H.; Hofman, B.; Rauscher, A. Anodic polarization of cemented carbides of the type [(WC, $\mathrm{M}) ; \mathrm{M}=\mathrm{Fe}, \mathrm{Ni}$ or $\mathrm{Co}]$ in sulphuric acid solution. Electrochim. Acta 1992, 37, 447-452.

75. Lee, K.; Ishihara, A.; Mitsushima, S.; Kamiya, N.; Ota, K. Stability and electrocatalytic activity for oxygen reduction in WC + Ta catalyst. Electrochim. Acta 2004, 49, 3479-3485.

76. Weigert, E.C.; Esposito, D.V.; Chen, J.G. Cyclic voltammetry and X-ray photoelectron spectroscopy studies of electrochemical stability of clean and Pt-modified tungsten and molybdenum carbide (WC and $\mathrm{Mo}_{2} \mathrm{C}$ ) electrocatalysts. J. Power Sources 2009, 193, 501-506.

77. Jeon, M.K.; Daimon, H.; Lee, K.R.; Nakahara, A.; Woo, S.I. CO tolerant Pt/WC methanol electro-oxidation catalyst. Electrochem. Commun. 2007, 9, 2692-2695.

78. McIntyre, D.R.; Burstein, G.T.; Vossen, A. Effect of carbon monoxide on the electrooxidation of hydrogen by tungsten carbide. J. Power Sources 2002, 107, 67-73.

79. Ham, D.J.; Kim, Y.K.; Han, S.H.; Lee, J.S. Pt/WC as an anode catalyst for PEMFC: Activity and CO tolerance. Catal. Today 2008, 132, 117-122.

80. Hwu, H.H.; Polizzotti, B.D.; Chen, J.G. Potential application of tungsten carbides as electrocatalysts. 2. Coadsorption of $\mathrm{CO}$ and $\mathrm{H}_{2} \mathrm{O}$ on carbide-modified W(111). J. Phys. Chem. B 2001, 105, 10045-10053.

81. Weigert, E.C.; Zellner, M.B.; Stottlemyer, A.L.; Chen, J.G. A combined surface science and electrochemical study of tungsten carbides as anode electrocatalysts. Top. Catal. 2007, 46, 349-357.

82. Hara, Y.; Minami, N.; Itagaki, H. Synthesis and characterization of high-surface area tungsten carbides and application to electrocatalytic hydrogen oxidation. Appl. Catal. A. 2007, 323, 86-93.

83. Ganesan, R.; Lee, J.S. Tungsten carbide microspheres as a noble-metal-economic electrocatalyst for methanol oxidation. Angew. Chem. Int. Ed. 2005, 44, 6557-6560.

84. Ganesan, R.; Ham, D.J.; Lee, J.S. Platinized mesoporous tungsten carbide for electrochemical methanol oxidation. Electrochem. Commun. 2007, 9, 2576-2579. 
85. Nagai, M.; Yoshida, M.; Tominaga, H. Tungsten and nickel tungsten carbides as anode electrocatalysts. Electrochim. Acta 2007, 52, 5430-5436.

86. Yang, X.G.; Wang, C.Y. Nanostructured tungsten carbide catalysts for polymer electrolyte fuel cells. Appl. Phys. Lett. 2005, 86, 224104.

87. Hwu, H.H.; Chen, J.G.; Kourtakis, K.; Lavin, J.G. Potential application of tungsten carbides as electrocatalysts. 1. Decomposition of methanol over carbide-modified W(111). J. Phys. Chem. B 2001, 105, 10037-10044.

88. Liu, N.; Kourtakis, K.; Figueroa, J.C.; Chen, J.G. Potential application of tungsten carbides as electrocatalysts III. Reactions of methanol, water, and hydrogen on Pt-modified C/W(111) surfaces. J. Catal. 2003, 215, 254-263.

89. Weigert, E.C.; Stottlemyer, A.L.; Zellner, M.B.; Chen, J.G. Tungsten monocarbide as potential replacement of platinum for methanol electrooxidation. J. Phys. Chem. C 2007, 111, 14617-14620.

90. Joo, J.B.; Kim, J.S.; Kim, P.; Yi, J. Simple preparation of tungsten carbide supported on carbon for use as a catalyst support in a methanol electro-oxidation. Mater. Lett. 2008, 62, 3497-3499.

91. Wang, Z.; Zuo, P.; Liu, B.; Yin, G.; Shi, P. Stable PtNiPb/WC catalyst for direct methanol fuel cells. Electrochem. Solid State Lett. 2009, 12, A13-A15.

92. Zhao, Z.; Fang, X.; Li, Y.; Wang, Y.; Shen, P.K.; Xie, F.; Zhang, X. The origin of the high performance of tungsten carbides/carbon nanotubes supported $\mathrm{Pt}$ catalysts for methanol electrooxidation. Electrochem. Commun. 2009, 11, 290-293.

93. Wang, R.; Tian, C.; Wang, L.; Wang, B.; Zhang, H.; Fu, H. In situ simultaneous synthesis of WC/graphitic carbon nanocomposite as a highly efficient catalyst support for DMFC. Chem. Comm. 2009, 21, 3104-3106.

94. Hwu, H.H.; Chen, J.G. Reactions of methanol and water over carbide-modified Mo(110). Surf. Sci. 2003, 536, 75-87.

95. Zellner, M.B.; Hwu, H.H.; Chen, J.G. Comparative studies of methanol decomposition on carbide-modified V(110) and Ti(0001). Surf. Sci. 2005, 598, 185-199.

96. Hu, F.; Cui, G.; Wei, Z.; Shen, P.K. Improved kinetics of ethanol oxidation on Pd catalysts supported on tungsten carbides/carbon nanotubes. Electrochem. Commun. 2008, 10, 1303-1306.

97. Nie, M.; Tang, H.; Wei, Z.; Jiang, S.P.; Shen, P.K. Highly efficient AuPd-WC/C electrocatalyst for ethanol oxidation. Electrochem. Commun. 2007, 9, 2375-2379.

98. Chhina, H.; Campbell, S.; Kesler, O. Thermal and electrochemical stability of tungsten carbide catalyst supports. J. Power Sources 2007, 164, 431-440.

99. Meng, H.; Shen, P.K. Novel Pt-free catalyst for oxygen electroreduction. Electrochem. Commun. 2006, 8, 588-594.

100. Meng, H.; Shen, P.K. Tungsten carbide nanocrystal promoted Pt/C electrocatalysts for oxygen reduction. J. Phys. Chem. B 2005, 109, 22705-22709.

101. Nie, M.; Shen, P.K.; Wei, Z. Nanocrystaline tungsten carbide supported Au-Pd electrocatalyst for oxygen reduction. J. Power Sources 2007, 167, 69-73.

102. Lee, J.S.; Hyun, T.H. Metal nitrides. In Encyclopedia of Catalysis, 1st ed.; Horvath, I.T., Ed.; John Wiley \& Sons: New York, NY, USA, 2003. 
103. Ponce, F.A.; Moustakas, T.D.; Akasaki, I.; Monemar, B.A. III-V Nitrides; Materials Research Society: Warrendale, PA, USA, 1997.

104. Markel, E.J.; Leaphart, M.E.; Howe-Grant, M.E. Encyclopedia of Chemical Technology; John Wiley \& Sons: New York, NY, USA, 1992.

105. Chen, J.G. Carbide and nitride overlayers on early transition metal surfaces: preparation, characterization, and reactivities. Chem. Rev. 1996, 96, 1477-1498.

106. Choi, D.; Kumta, P.N. Synthesis, structure, and electrochemical characterization of nanocrystalline tantalum and tungsten nitrides. J. Am. Ceram. Soc. 2007, 90, 3113-3120.

107. Roberson, S.L.; Finello, D.; Davis, R.F. Electrochemical evaluation of molybdenum nitride electrodes in $\mathrm{H}_{2} \mathrm{SO}_{4}$ electrolyte. J. Appl. Electrochem. 1999, 29, 75-80.

108. Francois, J.C.; Massiani, Y.; Gravier, P.; Grimblot, J.; Gengembre, L. Characterization and optical properties of thin films formed on TiN coatings during electrochemical treatments. Thin Solid Films 1993, 223, 223-229.

109. Walther, B.; Schilm, J.; Michaelis, A.; Lohrengel, M.M. Electrochemical dissolution of hard metal alloys. Electrochim. Acta 2007, 52, 7732-7737.

110. Subramanian, B.; Jayachandran, M. Electrochemical corrosion behavior of magnetron sputtered TiN coated steel in simulated bodily fluid and its hemocompatibility. Mater. Lett. 2008, 62, 1727-1730.

111. Musthafa, O.T.M.; Sampath, S. High performance platinized titanium nitride catalyst for methanol oxidation. Chem. Comm. 2008, 7, 67-69.

112. Zhong, H.; Zhang, H.; Liang, Y.; Zhang, J.; Wang, M.; Wang, X. A novel non-noble electrocatalyst for oxygen reduction in proton exchange membrane fuel cells. J. Power Sources 2007, 164, 572-577.

113. Xia, D.; Liu, S.; Wang, Z.; Chen, G.; Zhang, L.; Zhang, L.; Hui, S.; Zhang, J. Methanol-tolerant MoN electrocatalyst synthesized through heat treatment of molybdenum tetraphenylporphyrin for four-electron oxygen reduction reaction. J. Power Sources 2008, 177, 296-302.

114. Zhong, H.; Zhang, H.; Liu, G.; Liang, Y.; Hu, J.; Yi, B. A novel non-noble electrocatalyst for PEM fuel cell based on molybdenum nitride. Electrochem. Commun. 2006, 8, 707-712.

(C) 2009 by the authors; licensee Molecular Diversity Preservation International, Basel, Switzerland. This article is an open-access article distributed under the terms and conditions of the Creative Commons Attribution license (http://creativecommons.org/licenses/by/3.0/). 